4

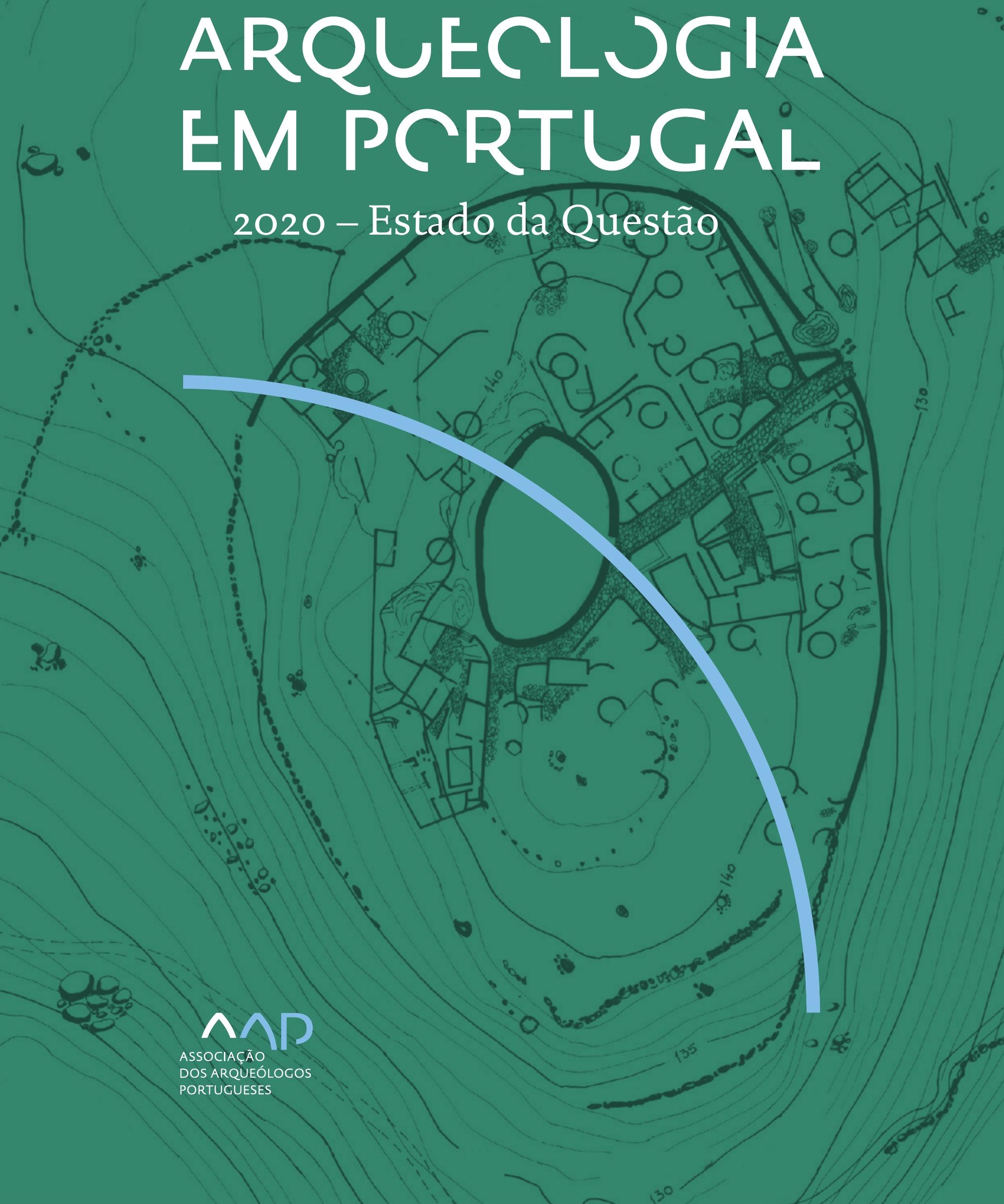


Coordenação editorial: José Morais Arnaud, César Neves e Andrea Martins Design gráfico: Flatland Design

AAP - ISBN: 978-972-9451-89-8

CITCEM - ISBN: 978-989-8970-25-1

Associação dos Arqueólogos Portugueses e CITCEM

Lisboa, 2020

O conteúdo dos artigos é da inteira responsabilidade dos autores. Sendo assim a Associação dos Arqueólogos Portugueses declina qualquer responsabilidade por eventuais equívocos ou questões de ordem ética e legal.

Desenho de capa:

Planta do castro de Monte Mozinho (Museu Municipal de Penafiel).

\section{$\hat{\wedge} \mathrm{P}$}

DOS ARQUEÓLOGOS PORTUGUESES

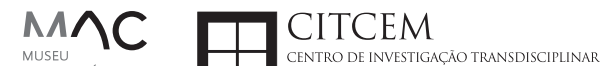
MUSEU
ARQUELLÓGICO
DO CARMO
U.PORTO

FLUP FACULDADE DE LETRAS
UNIVERSIDADE DO PORTO

Apoio

EC para a Ciência 


\section{Índice}

15 Prefácio

José Morais Arnaud

\section{Historiografia e Teoria}

17 Território, comunidade, memória e emoção: a contribuição da história da arqueologia (algumas primeiras e breves reflexões)

Ana Cristina Martins

25 Como descolonizar a arqueologia portuguesa?

Rui Gomes Coelho

41 Arqueologia e Modernidade: uma revisitação pessoal e breve de alguns aspetos da obra homónima de Julian Thomas de 2004

Vítor Oliveira Jorge

57 Dados para a História das Mulheres na Arqueologia portuguesa, dos finais do século XIX aos inícios do século XX: números, nomes e tabelas

Filipa Dimas / Mariana Diniz

73 Retractos da arqueologia portuguesa na imprensa: (in)visibilidades no feminino

Catarina Costeira / Elsa Luís

85 Arqueologia e Arqueólogos no Norte de Portugal Jacinta Bugalhão

101 Vieira Guimarães (1864-1939) e a arqueologia em Tomar: uma abordagem sobre o território e as gentes

João Amendoeira Peixoto / Ana Cristina Martins

115 Os memoráveis? A arqueologia algarvia na imprensa nacional e regional na presente centúria (2001-2019): características, visões do(s) passado(s) e a arqueologia

enquanto marca

Frederico Agosto / João Silva

129 A Evolução da Arqueologia Urbana e a Valorização Patrimonial no Barlavento Algarvio: Os casos de Portimão e Silves

Artur Mateus / Diogo Varandas / Rafael Boavida

\section{Gestão, Valorização e Salvaguarda do Património}

145 O Caderno Reivindicativo e as condições de trabalho em Arqueologia Miguel Rocha / Liliana Matias Carvalho / Regis Barbosa / Mauro Correia / Sara Simões / Jacinta Bugalhão / Sara Brito / Liliana Veríssimo Carvalho / Richard Peace / Pedro Peça / Cézer Santos

155 Os Estudos de Impacte Patrimonial como elemento para uma estratégia sustentável de minimização de impactes no âmbito de reconversões agrícolas Tiago do Pereiro

165 Salvaguarda de Património arqueológico em operações florestais: gestão e sensibilização Filipa Bragança / Gertrudes Zambujo / Sandra Lourenço / Belém Paiva / Carlos Banha / Frederico Tatá Regala / Helena Moura / Jacinta Bugalhão / João Marques / José Correia / Pedro Faria / Samuel Melro

179 Os valores do Património: uma investigação sobre os Sítios Pré-históricos de Arte Rupestre do Vale do Rio Côa e de Siega Verde José Paulo Francisco 
189 Conjugando recursos arqueológicos e naturais para potenciar as visitas ao Geoparque Litoral de Viana do Castelo (Noroeste de Portugal)

Hugo A. Sampaio / Ana M.S. Bettencourt / Susana Marinho / Ricardo Carvalhido

203 Áreas de Potencial Arqueológico na Região do Médio Tejo: Modelo Espacial Preditivo Rita Ferreira Anastácio / Ana Filipa Martins / Luiz Oosterbeek

223 Património Arqueológico e Gestão Territorial: O contributo da Arqueologia para a revisão do PDM de Avis

Ana Cristina Ribeiro

237 A coleção arqueológica do extinto Museu Municipal do Porto - Origens, Percursos e Estudos

Sónia Couto

251 Valpaços - uma nova carta arqueológica

Pedro Pereira / Maria de Fátima Casares Machado

263 Arqueologia na Cidade de Peniche

Adriano Constantino / Luís Rendeiro

273 Arqueologia Urbana: a cidade de Lagos como caso de Estudo Cátia Neto

285 Estratégias de promoção do património cultural subaquático nos Açores. O caso da ilha do Faial

José Luís Neto / José Bettencourt / Luís Borges / Pedro Parreira

297 Carta Arqueológica da Cidade Velha: Uma primeira abordagem

Jaylson Monteiro / Nireide Tavares / Sara da Veiga / Claudino Ramos / Edson Brito /

Carlos Carvalho / Francisco Moreira / Adalberto Tavares

311 Antropologia Virtual: novas metodologias para a análise morfológica e funcional Ricardo Miguel Godinho / Célia Gonçalves

\section{Didáctica da Arqueologia}

327 Como os projetos de Arqueologia podem contribuir para uma comunidade culturalmente mais consciente Alexandra Figueiredo / Claúdio Monteiro / Adolfo Silveira / Ricardo Lopes

337 Educação Patrimonial - Um cidadão esclarecido é um cidadão ativo! Ana Paula Almeida

351 A aproximação da Arqueologia à sala de aula: um caso de estudo no $3^{\circ}$ ciclo do Ensino Básico Luís Serrão Gil

363 Arqueologia 3.o - Pensar e comunicar a Arqueologia para um futuro sustentável Mónica Rolo

377 “Conversa de Arqueólogos" - Divulgar a Arqueologia em tempos de Pandemia Diogo Teixeira Dias

389 Escola Profissional de Arqueologia: desafios e oportunidades Susana Nunes / Dulcineia Pinto / Júlia Silva / Ana Mascarenhas

399 Os Museus de Arqueologia e os Jovens: a oferta educativa para o público adolescente Beatriz Correia Barata / Leonor Medeiros

411 O museu universitário como mediador entre a ciência e a sociedade: o exemplo da secção de arqueologia no Museu de História Natural e da Ciência da Universidade do Porto (MHNC-UP)

Rita Gaspar 
421 Museu de Lanifícios: Real Fábrica de Panos. Atividades no âmbito da Arqueologia Beatriz Correia Barata / Rita Salvado

427 Arqueologia Pública e o caso da localidade da Mata (Torres Novas) Cláudia Manso / Ana Rita Ferreira / Cristiana Ferreira / Vanessa Cardoso Antunes

431 Do sítio arqueológico ao museu: um percurso (também) didático Lídia Fernandes

447 Estão todos convidados para a Festa! E para dançar também... O projecto do Serviço Educativo do Museu Arqueológico do Carmo na $5^{\underline{a}}$ Edição da Festa da Arqueologia Rita Pires dos Santos

459 O “Clã de Carenque”, um projeto didático de arqueologia Eduardo Gonzalez Rocha

469 Mediação cultural: peixe que puxa carroça nas Ruínas Romanas de Troia Inês Vaz Pinto / Ana Patrícia Magalhães / Patrícia Brum / Filipa Santos

481 Didática Arqueológica, experiências do Projeto Mértola Vila Museu Maria de Fátima Palma / Clara Rodrigues / Susana Gómez / Lígia Rafael

\section{Arte Rupestre}

497 Os inventários de arte rupestre em Portugal Mila Simões de Abreu

513 O projeto FIRST-ART - conservação, documentação e gestão das primeiras manifestações de arte rupestre no Sudoeste da Península Ibérica: as grutas do Escoural e Maltravieso Sara Garcês / Hipólito Collado / José Julio García Arranz / Luiz Oosterbeek / António Carlos Silva / Pierluigi Rosina / Hugo Gomes / Anabela Borralheiro Pereira / George Nash / Esmeralda Gomes / Nelson Almeida / Carlos Carpetudo

523 Trabalhos de documentação de arte paleolítica realizados no âmbito do projeto PalæoCôa André Tomás Santos / António Fernando Barbosa / Luís Luís / Marcelo Silvestre / Thierry Aubry

537 Imagens fantasmagóricas, silhuetas elusivas: as figuras humanas na arte do Paleolítico Superior da região do Côa Mário Reis

$55^{1}$ Os motivos zoomórficos representados nas placas de tear de Vila Nova de São Pedro (Azambuja, Portugal) Andrea Martins / César Neves / José M. Arnaud / Mariana Diniz

571 Arte Rupestre do Monte de Góios (Lanhelas, Caminha). Síntese dos resultados dos trabalhos efectuados em 2007-2009 Mário Varela Gomes

599 Gravuras rupestres de barquiformes no Monte de S. Romão, Guimarães, Noroeste de Portugal Daniela Cardoso

613 Círculos segmentados gravados na Bacia do Rio Lima (Noroeste de Portugal): contributos para o seu estudo Diogo Marinho / Ana M.S. Bettencourt / Hugo Aluai Sampaio

631 Equídeos gravados no curso inferior do Rio Mouro, Monção (NW Portugal). Análise preliminar Coutinho, L.M. / Bettencourt, A.M.S / Sampaio, Hugo A.S

645 Paletas na Arte Rupestre do Noroeste de Portugal. Inventário preliminar Bruna Sousa Afonso / Ana M. S. Bettencourt / Hugo A. Sampaio 


\section{Pré-História}

661 O projeto Miño/Minho: balanço de quatro anos de trabalhos arqueológicos Sérgio Monteiro-Rodrigues / João Pedro Cunha-Ribeiro / Eduardo Méndez-Quintas / Carlos Ferreira / Pedro Xavier / José Meireles / Alberto Gomes / Manuel Santonja / Alfredo Pérez-González

677 A ocupação paleolítica da margem esquerda do Baixo Minho: a indústria lítica do sítio de Pedreiras 2 (Monção, Portugal) e a sua integração no contexto regional Carlos Ferreira / João Pedro Cunha-Ribeiro / Sérgio Monteiro-Rodrigues / Eduardo Méndez-Quintas / Pedro Xavier / José Meireles / Alberto Gomes / Manuel Santonja / Alfredo Pérez-González

693 O sítio acheulense do Plistocénico médio da Gruta da Aroeira Joan Daura / Montserrat Sanz / Filipa Rodrigues / Pedro Souto / João Zilhão

703 As sociedades neandertais no Barlavento algarvio: modelos preditivos com recurso aos SIG

Daniela Maio

715 A utilização de quartzo durante o Paleolítico Superior no território dos vales dos rios Vouga e Côa

Cristina Gameiro / Thierry Aubry / Bárbara Costa / Sérgio Gomes / Luís Luís / Carmen Manzano / André Tomás Santos

733 Uma perspetiva diacrónica da ocupação do concheiro do Cabeço da Amoreira (Muge, Portugal) a partir da tecnologia lítica Joana Belmiro / João Cascalheira / Célia Gonçalves

745 Novos dados sobre a Pré-história Antiga no concelho de Palmela. A intervenção arqueológica no sítio do Poceirão I

Michelle Teixeira Santos

757 Problemas em torno de Datas Absolutas Pré-Históricas no Norte do Alentejo Jorge de Oliveira

771 Povoamento pré-histórico nas áreas montanhosas do NO de Portugal: o Abrigo 1 de Vale de Cerdeira Pedro Xavier / José Meireles / Carlos Alves

783 Apreciação do povoamento do Neolítico Inicial na Baixa Bacia do Douro. A Lavra I (Serra da Aboboreira) como caso de estudo Maria de Jesus Sanches

797 O Processo de Neolitização na Plataforma do Mondego: os dados do Sector C do Outeiro dos Castelos de Beijós (Carregal do Sal)

João Carlos de Senna-Martinez / José Manuel Quintã Ventura / Andreia Carvalho / Cíntia Maurício

823 Novos trabalhos na Lapa da Bugalheira (Almonda, Torres Novas) Filipa Rodrigues / Pedro Souto / Artur Ferreira / Alexandre Varanda / Luís Gomes / Helena Gomes / João Zilhão

837 A pedra polida e afeiçoada do sítio do Neolítico médio da Moita do Ourives (Benavente, Portugal)

César Neves

857 Casal do Outeiro (Encarnação, Mafra): novos contributos para o conhecimento do povoamento do Neolítico final na Península de Lisboa.

Cátia Delicado / Carlos Maneira e Costa / Marta Miranda / Ana Catarina Sousa

873 Stresse infantil, morbilidade e mortalidade no sítio arqueológico do Neolítico Final/ Calcolítico ( $4^{\circ}$ e $3^{\circ}$ milénio a.C.) do Monte do Carrascal 2 (Ferreira do Alentejo, Beja) Liliana Matias de Carvalho / Sofia N. Wasterlain 
885 Come together: O Conjunto Megalítico das Motas (Monção, Viana do Castelo) e as expressões Campaniformes do Alto Minho Ana Catarina Basílio / Rui Ramos

899 Trabalhos arqueológicos no sítio Calcolítico da Pedreira do Poio Carla Magalhães / João Muralha / Mário Reis / António Batarda Fernandes

913 O sítio arqueológico de Castanheiro do Vento. Da arquitectura do sítio à arquitectura de um território João Muralha Cardoso

925 Estudo zooarqueológico das faunas do Calcolítico final de Vila Nova de São Pedro (Azambuja, Portugal): Campanhas de 2017 e 2018 Cleia Detry / Ana Catarina Francisco / Mariana Diniz / Andrea Martins / César Neves / José Morais Arnaud

943 As faunas depositadas no Museu Arqueológico do Carmo provenientes de Vila Nova de São Pedro (Azambuja): as campanhas de 1937 a 1967 Ana Catarina Francisco / Cleia Detry / César Neves / Andrea Martins / Mariana Diniz / José Morais Arnaud

959 Análise funcional de material lítico em sílex do castro de Vila Nova de S. Pedro (Azambuja, Portugal): uma primeira abordagem Rafael Lima

971 O recinto da Folha do Ouro 1 (Serpa) no contexto dos recintos de fossos calcolíticos alentejanos

António Carlos Valera / Tiago do Pereiro / Pedro Valério / António M. Monge Soares

\section{Proto-História}

987 Produção de sal marinho na Idade do Bronze do noroeste Português. Alguns dados para uma reflexão

Ana M. S. Bettencourt / Sara Luz / Nuno Oliveira / Pedro P. Simões / Maria Isabel C. Alves / Emílio Abad-Vidal

1001 A estátua-menir do Pedrão ou de São Bartolomeu do Mar (Esposende, noroeste de Portugal) no contexto arqueológico da fachada costeira de entre os rios Neiva e Cávado Ana M. S. Bettencourt / Manuel Santos-Estévez / Pedro Pimenta Simões / Luís Gonçalves

1015 O Castro do Muro (Vandoma/Baltar, Paredes) - notas para uma biografia de ocupação da Idade do Bronze à Idade Média

Maria Antónia D. Silva / Ana M. S. Bettencourt / António Manuel S. P. Silva / Natália Félix

1031 Do Bronze Final à Idade Média - continuidades e hiatos na ocupação de Povoados em Oliveira de Azeméis João Tiago Tavares / Adriaan de Man

1041 As faunas do final da Idade do Bronze no Sul de Portugal: leituras desde o Outeiro do Circo (Beja)

Nelson J. Almeida / Íris Dias / Cleia Detry / Eduardo Porfírio / Miguel Serra

1055 A Espada do Monte das Oliveiras (Serpa) - uma arma do Bronze Pleno do Sudoeste Rui M. G. Monge Soares / Pedro Valério / Mariana Nabais / António M. Monge Soares

1065 São Julião da Branca (Albergaria-a-Velha) - Investigação e valorização de um povoado do Bronze Final

António Manuel S. P. Silva / Paulo A. P. Lemos / Sara Almeida e Silva / Edite Martins de Sá

1083 Do castro de S. João ao Mosteiro de Santa Clara: notícia de uma intervenção arqueológica, em Vila do Conde Rui Pinheiro 
1095 O castro de Ovil (Espinho), um quarto de século de investigação - resultados e questões em aberto

Jorge Fernando Salvador / António Manuel S. P. Silva

1111 O Castro de Salreu (Estarreja), um povoado proto-histórico no litoral do Entre Douro e Vouga

Sara Almeida e Silva / António Manuel S. P. Silva / Paulo A. P. Lemos / Edite Martins de Sá

1127 Castro de Nossa Senhora das Necessidades (Sernancelhe): uma primeira análise artefactual Telma Susana O. Ribeiro

${ }_{1141}$ A cividade de Bagunte. O estado atual da investigação Pedro Brochado de Almeida

1153 Zoomorfos na cerâmica da Idade do Ferro no NW Peninsular: inventário, cronologias e significado Nuno Oliveira / Cristina Seoane

1163 Vasos gregos em Portugal: diferentes maneiras de contar a história do intercâmbio cultural na Idade do Ferro

Daniela Ferreira

1175 Os exotica da necrópole da Idade do Ferro do Olival do Senhor dos Mártires (Alcácer do Sal) no seu contexto regional

Francisco B. Gomes

\section{Antiguidade Clássica e Tardia}

1191 O uso de madeira como combustível no sítio da Quinta de Crestelos (Baixo Sabor): da Idade do Ferro à Romanização Filipe Vaz / João Tereso / Sérgio Simões Pereira / José Sastre / Javier Larrazabal Galarza / Susana Cosme / José António Pereira / Israel Espi

1207 Cultivos de Época Romana no Baixo Sabor: continuidade em tempos de mudança? João Pedro Tereso / Sérgio Simões Pereira / Filipe Santos / Luís Seabra / Filipe Vaz

1221 A casa romana na Hispânia: aplicação dos modelos itálicos nas províncias ibéricas Fernanda Magalhães / Diego Machado / Manuela Martins

1235 As pinturas murais romanas da Rua General Sousa Machado, n. ${ }^{5}$ 1, Chaves José Carvalho

1243 Trás do Castelo (Vale de Mir, Pegarinhos, Alijó) - Uma exploração agrícola romana do Douro

Tony Silvino / Pedro Pereira

1255 A sequência de ocupação no quadrante sudeste de Bracara Augusta: as transformações de uma unidade doméstica Lara Fernandes / Manuela Martins

1263 Os Mosaicos com decoração geométrica e geométrico-vegetalista dos sítios arqueológicos da área do Conuentus Bracaraugustanus. Novas abordagens quanto à conservação, restauro, decoração e datação Maria de Fátima Abraços / Licínia Wrench

1277 “Casa Romana” do Castro de São Domingos (Cristelos, Lousada): Escavação, Estudo e Musealização Paulo André de P. Lemos

1291 A arqueobotânica no Castro de Guifões (Matosinhos, Noroeste de Portugal): O primeiro estudo carpológico

Luís Seabra / Andreia Arezes / Catarina Magalhães / José Varela / João Pedro Tereso 
1305 Um Horreum Augustano na Foz do Douro (Monte do Castelo de Gaia, Vila Nova de Gaia) Rui Ramos

1311 Ponderais romanos na Lusitânia: padrões, formas, materiais e contextos de utilização Diego Barrios Rodríguez

1323 Um almofariz centro-itálico na foz do Mondego

Marco Penajoia

1335 Estruturas romanas de Carnide - Lisboa Luísa Batalha / Mário Monteiro / Guilherme Cardoso

1347 O contexto funerário do sector da "necrópole NO" da Rua das Portas de S. Antão (Lisboa): o espaço, os artefactos, os indivíduos e a sua interconectividade na interpretação do passado Sílvia Loja, José Carlos Quaresma, Nelson Cabaço, Marina Lourenço, Sílvia Casimiro, Rodrigo Banha da Silva, Francisca Alves-Cardoso

${ }_{1361}$ Povoamento em época Romana na Amadora - resultados de um projeto pluridisciplinar Gisela Encarnação / Vanessa Dias

1371 A Arquitectura Residencial em Mirobriga (Santiago do Cacém): contributo a partir de um estudo de caso Filipe Sousa / Catarina Felício

${ }_{1385}$ O fim do ciclo. Saneamento e gestão de resíduos nos edifícios termais de Mirobriga (Santiago do Cacém)

Catarina Felício / Filipe Sousa

1399 Balsa, Topografia e Urbanismo de uma Cidade Portuária Vítor Silva Dias / João Pedro Bernardes / Celso Candeias / Cristina Tété Garcia

1413 No Largo das Mouras Velhas em Faro (2017): novas evidências da necrópole norte de Ossonoba e da sua ocupação medieval Ricardo Costeira da Silva / Paulo Botelho / Fernando Santos / Liliana Nunes

1429 Instrumentos de pesca recuperados numa fábrica de salga em Ossonoba (Faro) Inês Rasteiro / Ricardo Costeira da Silva / Paulo Botelho

1439 A Necrópole Romana do Eirô, Duas Igrejas (Penafiel): intervenção arqueológica de 2016 Laura Sousa / Teresa Soeiro

1457 Ritual, descarte ou afetividade? A presença de Canis lupus familiaris na Necrópole Noroeste de Olisipo (Lisboa)

Beatriz Calapez Santos / Sofia Simões Pereira / Rodrigo Banha da Silva / Sílvia Casimiro / Cleia Detry / Francisca Alves Cardoso

1467 Dinâmicas económicas em Bracara na Antiguidade Tardia Diego Machado / Manuela Martins / Fernanda Magalhães / Natália Botica

1479 Cerâmicas e Vidros da Antiguidade Tardia do Edifício sob a Igreja do Bom Jesus (Vila Nova de Gaia) Joaquim Filipe Ramos

1493 Novos contributos para a topografia histórica de Mértola no período romano e na Antiguidade Tardia Virgílio Lopes

\section{8. Época Medieval}

1511 Cerâmicas islâmicas no Garb setentrional "português": algumas evidências e incógnitas Constança dos Santos / Helena Catarino / Susana Gómez / Maria José Gonçalves / Isabel Inácio / Gonçalo Lopes / Jacinta Bugalhão / Sandra Cavaco / Jaquelina Covaneiro / Isabel Cristina Fernandes / Ana Sofia Gomes 
1525 Contributo para o conhecimento da cosmética islâmica, em Silves, durante a Idade Média Rosa Varela Gomes

1537 Yábura e o seu território - uma análise histórico-arqueológica de Évora entre os séculos VIII-XII José Rui Santos

1547 A encosta sul do Castelo de Palmela - resultados preliminares da escavação arqueológica Luís Filipe Pereira / Michelle Teixeira Santos

1559 A igreja de São Lourenço (Mouraria, Lisboa): um conjunto de silos e de cerâmica medieval islâmica

Andreia Filipa Moreira Rodrigues

1571 O registo material de movimentações populacionais no Médio Tejo, durante os séculos XII-XIII. Dois casos de "sunken featured buildings", nos concelhos de Cartaxo e Torres Novas Marco Liberato / Helena Santos / Nuno Santos

1585 O nordeste transmontano nos alvores da Idade média. Notas para reflexão Ana Maria da Costa Oliveira

1601 Sepulturas escavadas na rocha do Norte de Portugal e do Vale do Douro: primeiros resultados do Projecto SER-NPVD

Mário Jorge Barroca / César Guedes / Andreia Arezes / Ana Maria Oliveira

1619 "Portucalem Castrum Novum" entre o Mediterrâneo e o Atlântico: o estudo dos materiais cerâmicos alto-medievais do arqueossítio da rua de D. Hugo, nํ. 5 (Porto) João Luís Veloso

1627 A Alta Idade Média na fronteira de Lafões: notas preliminares sobre a Arqueologia no Concelho de Vouzela

Manuel Luís Real / Catarina Tente

1641 Um conjunto cerâmico medieval fora de portas: um breve testemunho aveirense Susana Temudo

${ }_{1651}$ Os Lóios do Porto: uma perspetiva integrada no panorama funerário da Baixa Idade Média à Época Moderna em meios urbanos em Portugal

Ana Lema Seabra

1659 O Caminho Português Interior de Santiago como eixo viário na Idade Média Pedro Azevedo

1665 Morfologia Urbana: Um exercício em torno do Castelo de Ourém André Donas-Botto / Jaqueline Pereira

1677 Intervenção arqueológica na Rua Marquês de Pombal/Largo do Espírito Santo (Bucelas, Loures)

Florbela Estêvão / Nathalie Antunes-Ferreira / Dário Ramos Neves / Inês Lisboa

1691 O Cemitério Medieval do Poço do Borratém e a espacialidade funerária na cidade de Lisboa Inês Belém / Vanessa Filipe / Vasco Noronha Vieira / Sónia Ferro / Rodrigo Banha da Silva

1705 Um Espaço Funerário Conventual do séc. XV em Lisboa: o caso do Convento de São Domingos da Cidade Sérgio Pedroso / Sílvia Casimiro / Rodrigo Banha da Silva / Francisca Alves Cardoso

\section{9. Época Moderna e Contemporânea}

1721 Arqueologia Moderna em Portugal: algumas reflexões críticas em torno da quantificação de conjuntos cerâmicos e suas inferências históricas e antropológicas Rodrigo Banha da Silva / André Bargão / Sara da Cruz Ferreira

1733 Faianças de dois contextos entre os finais do século XVI e XVIII do Palácio dos Condes de Penafiel, Lisboa

Martim Lopes / Tomás Mesquita 
1747 Um perfil de consumo do século XVIII na foz do Tejo: O caso do Mercado da Ribeira, Lisboa Sara da Cruz Ferreira / Rodrigo Banha da Silva / André Bargão

1761 Os Cachimbos dos Séculos XVII e XVIII do Palácio Mesquitela e Convento dos Inglesinhos (Lisboa)

Inês Simão / Marina Pinto / João Pimenta / Sara da Cruz Ferreira / André Bargão / Rodrigo Banha da Silva

1775 "Tomar os fumos da erua que chamão em Portugal erua sancta». Estudo de Cachimbos provenientes da Rua do Terreiro do Trigo, Lisboa

Miguel Martins de Sousa / José Pedro Henriques / Vanessa Galiza Filipe

1787 Cachimbos de Barro Caulínitico da Sé da Cidade Velha (República de Cabo Verde)

Rodrigo Banha da Silva / João Pimenta / Clementino Amaro

1801 Algumas considerações sobre espólio não cerâmico recuperado no Largo de Jesus (Lisboa) Carlos Boavida

1815 Adereços de vidro, dos séculos XVI-XVIII, procedentes do antigo Convento de Santana de Lisboa (anéis, braceletes e contas)

Joana Gonçalves / Rosa Varela Gomes / Mário Varela Gomes

1837 Da ostentação, luxo e poder à simplicidade do uso quotidiano: arqueologia e simbologia de joias e adornos da Idade Moderna Portuguesa Jéssica Iglésias

1849 Os amuletos em Portugal - dos objetos às superstições: o coral vermelho Alexandra Vieira

1865 Cerâmicas de Vila Franca de Xira nos séculos XV e XVI Eva Pires

1879 «Não passa por teu o que me pertence». Marcas de individualização associadas a faianças do Convento de Nossa Senhora de Aracoeli, Alcácer do Sal Catarina Parreira / Íris Fragoso / Miguel Martins de Sousa

1891 Cerâmica de Leiria: alguns focos de produção

Jaqueline Pereira / André Donas-Botto

1901 Os Fornos na Rua da Biquinha, em Óbidos Hugo Silva / Filipe Oliveira

1909 A casa de Pêro Fernandes, contador dos contos de D. Manuel I: o sítio arqueológico da Silha do Alferes, Seixal (século XVI) Mariana Nunes Ferreira

1921 O Alto da Vigia (Sintra) e a vigilância e defesa da costa Alexandre Gonçalves / Sandra Santos

1937 O contexto da torre sineira da Igreja de Santa Maria de Loures Paulo Calaveira / Martim Lopes

1949 A Necrópole do Hospital Militar do Castelo de São Jorge e as práticas funerárias na Lisboa de Época Moderna Susana Henriques / Liliana Matias de Carvalho / Ana Amarante / Sofia N. Wasterlain

1963 SAND - Sarilhos Grandes Entre dois Mundos: o adro da Igreja e a Paleobiologia dos ossos humanos recuperados

Paula Alves Pereira / Roger Lee Jesus / Bruno M. Magalhães

1975 Expansão urbana da vila de Cascais no século XVII e XVIII: a intervenção arqueológica na Rua da Vitória no 15 a 17

Tiago Pereira / Vanessa Filipe

1987 Novos dados para o conhecimento do Urbanismo de Faro em época Moderna Ana Rosa 
1995 Um exemplo de Arqueologia Urbana em Alcoutim: o Antigo Edifício dos CTT Marco Fernandes / Marta Dias / Alexandra Gradim / Virgílio Lopes / Susana Gómez Martínez

2007 Palácio dos Ferrazes (Rua das Flores/Rua da Vitória, Porto): a cocheira de Domingos Oliveira Maia

Francisco Raimundo

2021 As muitas vidas de um edifício urbano: História, Arqueologia e Antropologia no antigo Recreatório Paroquial de Penafiel Helena Bernardo / Jorge Sampaio / Marta Borges

2035 O convento de Nossa Senhora da Esperança de Ponta Delgada: o contributo da arqueologia para o conhecimento de um monumento identitário João Gonçalves Araújo / N’Zinga Oliveira

2047 Arqueologia na ilha do Corvo... em busca da capela de Nossa Senhora do Rosário Tânia Manuel Casimiro / José Luís Neto / Luís Borges / Pedro Parreira

2059 Perdidos à vista da Costa. Trabalhos arqueológicos subaquáticos na Barra do Tejo Jorge Freire / José Bettencourt / Augusto Salgado

2071 Arqueologia marítima em Cabo Verde: enquadramento e primeiros resultados do projecto CONCHA

José Bettencourt / Adilson Dias / Carlos Lima / Christelle Chouzenoux / Cristóvão Fonseca / Dúnia Pereira / Gonçalo Lopes / Inês Coelho / Jaylson Monteiro / José Lima / Maria Eugénia Alves / Patrícia Carvalho / Tiago Silva

2085 Trabalhos arqueológicos na Cidade Velha (Ribeira Grande de Santiago, Cabo Verde): reflexões sobre um projecto de investigação e divulgação patrimonial André Teixeira / Jaylson Monteiro / Mariana Mateus / Nireide Tavares / Cristovão Fonseca / Gonçalo C. Lopes / Joana Bento Torres / Dúnia Pereira / André Bargão / Aurélie Mayer / Bruno Zélie / Carlos Lima / Christelle Chouzenoux / Inês Henriques / Inês Pinto Coelho / José Lima / Patrícia Carvalho / Tiago Silva

2103 A antiga fortificação de Quelba / Khor Kalba (E.A.U.). Resultados de quatro campanhas de escavações, problemáticas e perspectivas futuras Rui Carita / Rosa Varela Gomes / Mário Varela Gomes / Kamyar Kamyad

2123 Colónias para homens novos: arqueologia da colonização agrária fascista no noroeste ibérico Xurxo Ayán Vila / José Mạ . Señorán Martín 


\title{
PROBLEMAS EM TORNO DE DATAS ABSOLUTAS PRÉ-HISTÓRICAS NO NORTE DO ALENTEJO
}

\author{
Jorge de Oliveira ${ }^{\mathrm{T}}$
}

\begin{abstract}
RESUMO
Nesta comunicação iremos apresentar todas as datas absolutas obtidas para contextos atribuídos à Pré-história recente do Alto Alentejo, mas cujos valores questionam o posicionamento cultural de alguns dos sítios. Tentaremos compreender as datas de radiocarbono do X ao VIII milénios a.C. em abrigos com arte rupestre esquemática. Trataremos os contextos das datas absolutas do VII ao V milénios a.C. em monumentos megalíticos funerários e, finalmente, divulgaremos, de novo, as datas absolutas obtidas em carvões recolhidos em alvéolos de menhires que os recuam mais de 2000 anos do que seria inicialmente suposto. Nesta comunicação trataremos também de um conjunto de datas de históricas obtidas a partir de carvões recolhidos em sítios atribuídos à Pré-História recente, mas com ocupações, ou visitas históricas que tentaremos contextualizar.

Palavras-chave: Datas absolutas, Pré-História, Norte do Alentejo, Problemas.
\end{abstract}

\begin{abstract}
In this communication we will present all the absolute dates obtained for contexts attributed to the recent prehistory of Alto Alentejo, but whose values question the cultural positioning of some of the sites. We will try to understand the radiocarbon dates from $10^{\text {th }}$ to the $8^{\text {th }}$ millennium $B C$ in shelters with schematic rock art. We will deal with the contexts of the absolute dates from the $7^{\text {th }}$ to the $5^{\text {th }}$ millennium B.C. in funerary megalithic monuments and, finally, we will disclose, again, the absolute dates obtained from coals collected in wells of menhirs that go back more than 2000 years from what was initially supposed. In this communication we will also deal with a set of historical dates obtained from coals collected from sites attributed to recent Prehistory, but with occupations, or historical visits that we will try to contextualize.
\end{abstract}

Keywords: Absolute dates, Prehistory, Northern Alentejo, Problems.

\section{O CONTEXTO}

No curto espaço que nos faculta esta comunicação teremos que apresentar de forma resumida as diferentes problemáticas contextuais das datações obtidas para sítios conotados com a Pré-História recente. Faremos essa apresentação, quer por cronologias, quer por contextos de recolha. No fim apresentaremos uma tabela-resumo de todas as datas obtidas e imagens dos contextos em que foram recolhidas. Foi só em 1982 que se obtiveram as primeiras datas por radiocarbono para a Pré-História no Norte do Alentejo. Os trabalhos de escavação e valorização da Anta da Bola da Cera, situada no concelho de Marvão, permitiram, pela primeira vez, obter datações absolutas sobre ossos humanos carbonizados "in situ" associados a placas de xisto de recorte e decoração antropomórficos. Iniciava-se, com este estudo, um longo ciclo de recolha e datação de amostras em diversos sítios com ocupação atribuída à pré-história recente no Distrito de Portalegre e canto Noroeste da Extremadura Espanhola. Trinta e oito anos decorridos contamos agora com um já significativo número de amostras datadas, mais de 30, podendo ser mais, não fosse os eternos constrangimentos orçamentais, que nos permitem compreender e aos mesmo tempo problematizar os posicionamentos cronométricos das mais importantes manifestações culturais da Pré-História Recente para esta zona da Península (Figura 1).

1. CHAIA / Universidade de Évora. 


\section{AS DATAS HISTÓRICAS}

Os estudos realizados em dólmenes de grande e média dimensão do corredor granítico Marvão Castelo de Vide - Nisa - Alter do Chão, nos pequenos sepulcros megalíticos das margens do Tejo, em território de Nisa e Cedillo (Espanha), nos abrigos com pinturas, maioritariamente esquemáticas, das cristas quartzíticas da Serra de Mamede, nos principais menhires dos concelhos de Marvão, Castelo de Vide e Nisa e nos dólmenes com menhires do concelho de Alter do Chão, permitem-nos apresentar hoje um amplo leque de datações absolutas que variam entre o $10^{\circ}$ milénio a.C. até ao séc. XVIII A.D.. Neste amplo leque cronológico há que isolar as datas históricas que se reportam, a estranhos episódios de fogueiras acesas no interior de grutas e dólmenes, ou junto a menhires em torno ao ano $1000 \mathrm{AD}$, que poderão estar estreitamente relacionados com episódios dos muito divulgados mitos apocalípticos dos "milenarismos". Não convém também esquecer as diversas datas históricas posicionadas em torno do período da denominada Reconquista Cristã que terá obrigado ao êxodo massivo dos núcleos urbanos por parte das comunidades aí estabelecidas a procurar grutas naturais isoladas para refúgio das espadas dos cavaleiros da cristandade e, por último, o enterramento dum equídeo num dólmen, pouco tempo depois da instalação, em terras do Reguengo de Alter do Chão, da Coudelaria Real, em 1748, durante o Reinado de D. João V, quando ainda não se tinha definido o "cemitério dos cavalos" naquela coudelaria. Haveria aqui que acrescentar, se dinheiro tivesse havido para submeter a datação mais amostras, os atos de visitação e violação de dólmenes para obtenção de sílex para pederneiras das armas de fogo nos séculos XVII e XVIII, como nos confirmam os documentos escritos que compulsámos, ou as reutilizações, quer como espaço funerário durante a romanização, como ocorreu no corredor da Anta da Tapada de Matos, em Castelo de Vide, ou como habitação, provavelmente de algum pastor romano na Anta da Soalheira, na Coudelaria de Alter (Figura 2 e 3). Haveria ainda que acrescentar a presença de carvões recentes e faiança de Coimbra (Prato Ratinho) em sepulcros megalíticos de xisto em terras de Cedillo. Aqui, como eventualmente noutros locais, aproveitavam estas pequenas sepulturas, que localmente ainda hoje são denominados de "hornillos", para conterem o fogo onde confecionavam os ali- mentos durante as jornadas de monda e ceifa, pelo menos entre o século XVIII e a primeira metade do século XX, tanto em terras da Extremadura Espanhola como do Alentejo. Deveríamos, também, se espaço houvesse que registar, pormenorizadamente, algumas ocorrências de tumulação e ocultação de cadáveres em sítios e monumentos arqueológicos pré-históricos, decorrentes de assassinatos perpetrados durante a Guerra Civil Espanhola, registados nos dois lados da fronteira, mas essa matéria não será aqui e por agora tratada.

\section{A COMPLEXIDADE CONTEXTUAL DAS DATAS PRÉ-HISTÓRICAS EM MONUMENTOS MEGALÍTICOS}

A datação dos menhires, sejam eles isolados ou em grupo, foi sempre tema de discussão entre os que estudam esta matéria. Se durante muitos foram, assumidamente considerados como contemporâneos dos grandes dólmenes, sobretudo, atendendo ao paralelismo da energia necessária para o seu transporte e ereção, desde a obtenção da data, à altura considerada extravagante, do Menhir da Meada que se começou a equacionar, ainda que com algumas renitências, a maior antiguidade dos menhires em relação ao período de ereção dos dólmenes mais complexos (Figura 4 e 5 ).

Praticamente só a partir dos finais da década de setenta do século XX é que se iniciaram trabalhos de escavação, cientificamente e diretamente dirigidos a menires. Infelizmente, ou porque os alvéolos estavam muito remexidos, ou porque, na verdade, nenhuma matéria orgânica se tivesse preservado foi necessário efetuarmos a escavação e reabilitação do Menir da Meada (Castelo de Vide), em 1993, para conseguirmos obter uma datação absoluta. Tratava-se duma amostra de carvão recolhida no fundo do alvéolo, encostado ao menir, em zona perfeitamente conservada, sob os blocos que calçavam o monumento e envolta em argila. Essa amostra submetida a datação por radio carbono forneceu a seguinte data: Utc-4452: 6022 + 40 BP, que calibrada a 2 sigmas resultou em 4810 a $5010 \mathrm{cal} \mathrm{BC}$. Na sequencia da divulgação pública desta data, em 1996, embora por muitos considerada como extravagante, a partir desse momento, a contemporaneidade dos menires e das antas começou claramente a ser questionada, sobretudo em relação aos monumentos funerários mais complexos, ainda que já anteriormente e ape- 
nas por via de análises estratigráficas se reconhecesse alguma anterioridade dos menires em relação aos dólmenes. Aqui devemos destacar o singular monumento da Granja de S. Pedro, em Idanha-a-Nova. Em boa verdade os investigadores que o estudaram afirmaram perentoriamente que os menires já aí se encontravam quando o sepulcro foi construído (Almeida e Ferreira, 1971). Outros estudos entretanto promovidos vieram reforçar o mais que provável posicionamento dos menires no Neolítico mais antigo. Toda a polémica que se gerou em torno dos Menires do Padrão a propósito da ligação cultural dos menires com os carvões da camada $\mathrm{C}_{2}$ que foi possível datar de meados dos 60 milénio (5480-5242 cal AC; 5580-5350 cal AC) (Gomes, 1997: 176), ou os materiais atribuídos ao Neolítico antigo identificados junto aos menires da Caramujeira (Gomes, 1997: 175), ainda que muito contestados e objeto de várias revisões e interpretações, somados às informações decorrentes dos trabalhos efetuados nos recintos megalíticos de Almendres e Portela de Mogos, junto dos quais se registaram ocupações atribuíveis, igualmente, ao Neolítico antigo, vinham, gradualmente, a reforçar a perceção da grande antiguidade destes monumentos. Se a data do menir da Meada foi então considerada duvidosa por ser muito mais antiga em relação ao espectável, todas as outras entretanto obtidas, maior controvérsia ainda gerou porque apenas, de uma forma indireta, se podiam ligar aos menires. No decurso da recente escavação e recuperação que promovemos no menir do Patalou, no concelho de Nisa, em 2016, foi-nos possível recolher e datar uma amostra de madeira carbonizada obtida no interior do alvéolo que forneceu a seguinte data: Beta- 416341: $5420+30 B P$, que calibrada resulta em Cal BC 4340 a 4235 (Cal BP 6290 a 6185). Com esta data agora obtida validava-se a que já anteriormente possuíamos para o Menir da Meada, cuja amostra de carvão foi recolhida em situação e contexto idêntico. Confirmava-se, assim, o posicionamento cultural dos menires no seio do Neolítico antigo e reafirma-se a anterioridade dos menires em relação, pelo menos, à fase plena do megalitismo dolménico. Se neste momento e para a região em apreço, pelo menos para os menires isolados, já temos um posicionamento crono-cultural seguro, importa agora compreender e relacionar estas datas com as obtidas para alguns monumentos megalíticos funerários, sobretudo para as amostras recolhidas em mamoas, ou na base dos sepulcros que se aproximam das datas dos menires e se afastam das datas obtidas a partir de restos ósseos recolhidos no interior destes espaços funerários, sejam eles simples ou mais complexos (Figura 6).

Se as datas obtidas para depósitos funerários no interior dos dólmenes e que até agora têm servido de referência para datar o megalitismo funerário $\left(3^{\mathrm{o}} \mathrm{a}\right.$ $4^{\circ}$ milénios a.C.) se afastam substancialmente das datas confirmadas para os menires da mesma região já outro conjunto de datas, algumas obtidas para os mesmos sepulcros, mas provenientes de unidades estratigráficas distintas, aproximam-se das cronologias obtidas para os menires e das recolhidas em ambientes de habitats conotados com o Neolítico antigo da mesma região. Paralelamente, temos vindo a registar um número crescente de menhires incorporados em sepulturas megalíticas, reaproveitados integralmente ou adaptados, como o que atualmente estudamos na Anta 1 dos Saragonheiros, em Nisa (monumento em fase de estudo).

Decorrem destas observações um conjunto de questões que estão por resolver e que se prendem, em grande medida, com a sequência, ou sequências cronológicas das manifestações megalíticas desta região. Parece ser hoje consensual a existência de uma grande anterioridade dos menires em relação aos sepulcros megalíticos do tipo dólmen. Se aceitarmos essa anterioridade, a presença, que começa a ser hoje já recorrente, de menires no interior de estruturas funerárias dolménicas, poderá ter, pelo menos, três explicações possíveis. A mais simplista dir-nos-ia que devido a uma economia de recursos, os construtores de dólmenes recorreriam àquelas pedras já talhadas e aproveitavam-nas para a construção dos sepulcros. Uma segunda hipótese dir-nos-á que a inclusão dos menires se ficaria a dever a algum ritual que obrigaria os construtores de antas a remover os menires e a incluí-los na sua estrutura. Uma terceira hipótese poderá tentar explicar esta ocorrência com a construção de um sepulcro no mesmo local onde já existia um menhir. Provavelmente todas as hipóteses poderão coexistir, contudo, e independentemente da existência, ou não, de menires na estrutura construtiva dos dólmenes, estão disponíveis, há já alguns anos, um conjunto de datas, consideradas demasiado antigas, recolhidas em dólmenes do Norte-Alentejano e "Extremadura" Espanhola, que se aproximam da data do Menir da Meada e do Patalou e, ao mesmo tempo, das datas, em geral, já disponíveis para habitats do Neolítico antigo, remetendo-nos, em anos de 
calendário, para o $\mathrm{V}$ e por vezes inícios do VI milénio BC. De facto, já muitas explicações foram aventadas para minimizar o impacto que estas datas antigas teriam nas interpretações tradicionais para a origem do megalitismo, que o remete sempre para momentos de um Neolítico médio e, maioritariamente, final. Na verdade, a maior parte das datas disponíveis para os dólmenes situa-se entre o IV e o III milénios, em anos de calendário, mas, igualmente, essas datas foram obtidas, maioritariamente, a partir de material ósseo. Contudo, é hoje totalmente aceite que estes sepulcros tiveram uma vida útil e funcional muito longa e com evidentes sinais de reutilizações, reabilitações e desenvolvimentos. Haverá que questionar, coisa que raramente foi feita, se as datações obtidas a partir de restos ósseos não datarão, maioritariamente, momentos finais de utilização e não do momento fundacional. Todos reconhecemos quão raro é encontrarem-se restos ósseos, passíveis de serem datados, localizados em terrenos xistosos, ou graníticos, terrenos que pela sua acidez destroem completamente a matéria orgânica. Provavelmente, teremos vindo, sucessivamente, a datar ossos de momentos finais de utilização destes sepulcros. Recorde-se que as datas mais antigas e consideradas anormais resultam, invariavelmente, de carvões que, por sistema, foram recolhidos na base dos monumentos ou, sob as respetivas mamoas, quando bem conservadas. Essas datações, porque iam contra as teorias aceites, foram sempre rejeitadas, considerando-se que se reportariam a episódios pré-megalíticos e, portanto, muito anteriores à construção dos sepulcros.

Se constatamos sinais evidentes de contemporaneidade entre a ereção dos grandes menhires do Norte do Alentejo e as datas obtidas para base dos monumentos funerários e reconhecemos a presença de menhires, claramente reutilizados nas estruturas dolménicas da mesma região, então teremos que posicionar culturalmente o início do megalitismo funerário e dos menhires na fase mais antiga do Neolítico. Suportados nestes dados teremos que aceitar que a "moda" de ereção de menires foi relativamente curta, sendo rapidamente absorvidos nos sepulcros megalíticos. A fase de ereção de menires deverá ter sido muito efémera, ou então, a explicação para as datas muito antigas nas antas e a presença de cerâmicas do Neolítico Antigo no seu interior terá que ter outra explicação. A tese das trasladações defendida por Leonor Rocha (Rocha, 2005), seguramente que é globalmente aceitável, num sentido lato, contudo não responde ao problema das datas antigas obtidas sob as mamoas. Anteriormente e com base em evidências claras, demonstrámos que alguns dos dólmenes estudados no nordeste alentejano foram construídos sobre habitats anteriores, onde ocorriam lareiras e silos (Oliveira, 1997 e 1998). Contudo, noutros casos tal situação não foi detetada, encontrando-se os sítios de habitat, todos do Neolítico antigo, bem definidos, nas imediações dos dólmenes.

O maior problema coloca-se quanto ao posicionamento relativo para a emergência dos menires. Se, de facto, eles já existiam ao tempo da construção dos primeiros dólmenes então, durante o Neolítico Antigo teremos que encontrar, pelo menos, duas fases. Uma mais antiga, durante a qual se ergueram menires e, posteriormente, uma fase de construção de sepulcros megalíticos que incorpora menires na sua estrutura funerária. A alternativa a esta interpretação poderá ser equacionada se se vier a definir, um dia, com precisão, o que se entende por Neolítico Médio. Para reequacionar toda esta problemática há necessidade de alargar as áreas de escavação das mamoas e dos habitats e, sobretudo, procurar encontrar matéria datável para nos ajudar a esclarecer, com precisão, a periodização do Neolítico no interior alentejano. Pelas datas de radiocarbono disponíveis para a bacia hidrográfica do Sever, embora apenas existam duas para sepulcros de pequena dimensão da zona xistosa, verificamos que estas caem dentro dos valores cronológicos médios dos monumentos de granito. Duas amostras de carvão recolhidas na anta da Joaniña, situada no Termo Municipal de Cedillo, forneceram, respetivamente, as seguintes idades: amostra A $-3840+170$ anos BP; amostra B $-5400+210$ anos BP. A primeira amostra refere-se a carvões identificados sobre o lajeado da base do monumento, associados a um machado de anfibolite e a uma ponta de seta de base triangular e a uma lâmina de sílex. A segunda amostra refere-se a carvões localizados entre o lajeado da base do monumento e o solão xistoso, em terras argilosas muito compactadas, sem materiais arqueológicos associados. Se a amostra $\mathrm{B}$ parece corresponder a carvões à data da construção do monumento, a segunda encontra-se perfeitamente situada nos contextos funerários megalíticos regionais, bastante próxima da data disponível para enterramentos na Anta da Bola Cera (monumento de granito de corredor curto), situada no concelho de Marvão. Esta amostra, obtida a partir de ossos huma- 
nos queimados aos quais se associava uma placa de xisto de recorte antropomórfico, forneceu a seguinte idade: $4360+50$ anos BP. Igualmente, a amostra $1 \mathrm{da}$ Anta da Cabeçuda, monumento de corredor curto, localizado no concelho de Marvão, correspondente a carvões recolhidos na base da câmara, associados a taças abertas que forneceu a seguinte idade: 3650 +110 anos BP. Um outro monumento, este de corredor longo, a anta IV dos Coureleiros, situada no concelho de Castelo de Vide, forneceu uma amostra de carvões recolhidos no corredor, associados a uma placa de xisto de recorte geométrico, que veio a dar a seguinte idade: $4240+150$ anos BP. Reconhece-se, assim, um perfeito enquadramento da amostra $\mathrm{A} d \mathrm{da}$ anta da Joaniña nos mesmos contextos cronológicos dos monumentos megalíticos de granito do Norte-Alentejano. No que à amostra B da anta da Joaniña diz respeito também ela é igualmente enquadrável no grupo das chamadas datas antigas do megalitismo da zona granítica. Neste grupo conhecem-se os seguintes valores: Amostra 2 da Anta das Castelhanas: $6300+110$ anos BP; Amostra 2 da Anta da Cabeçuda: 7660 + 6 o anos BP e Anta da Figueira Branca: $6210+50$ anos BP.

Parece, assim, não restarem dúvidas e com base em apenas duas datas da anta da Joaniña situada no Termo Municipal de Cedillo, que os pequenos monumentos megalíticos da foz do Sever são contemporâneos dos monumentos de maiores dimensões situados no patamar granítico da Serra de S. Mamede. Em face dos dados disponíveis parece não haver dúvidas quanto à contemporaneidade dos dois grupos de monumentos. As dissemelhanças na volumetria arquitetónica e nos conjuntos artefactuais resultariam, assim, de diferentes organizações socioecónomicas impostas pela especificidade de recursos existentes em cada zona. No que à origem dos menires diz respeito ela parece conviver com um período imediatamente anterior à emergência das primeiras sepulturas megalíticas e eventualmente haver ainda alguma convivência cultural entre as duas realidades mas durante um curto espaço de tempo, vindo a "cultura menírica" a perder importância à medida que o megalitismo funerário se afirmava na paisagem, incorporando direta ou indiretamente menhires ou porções deles nas suas estruturas.

\section{AS POSSÍVEIS INTERPRETAÇÕES PARA AS DATAS ABSOLUTAS OBTIDAS EM ABRIGOS PINTADOS}

No decurso dos nossos vários projetos de investigação sobre pré-história recente no Norte do Alentejo desenvolvemos, durante vários anos, campanhas de estudo, algumas com escavação, em abrigos naturais com pinturas esquemáticas existentes nas cristas quartzíticas da Serra de S. Mamede, acidente natural que domina toda a área que temos vindo a tratar. Para além das prospeções efetuadas que nos possibilitam, neste momento, reconhecer a existência de mais de trinta sítios com arte pintada ao longo da Serra de S. Mamede e seus contrafortes e que acrescentaram substancialmente o conhecimento que se se tinha até 2005 e que se resumia apenas a quatro abrigos em território português e os que se conheciam em S. Braz, junto a Albuquerque, em território espanhol procedemos à abertura de sondagens no interior e exterior do Abrigo da Igreja dos Mouros, no exterior do Abrigo dos Gaivões e no interior do Abrigo Pinho Monteiro, todos situados na freguesia de Esperança, no concelho de Arronches. Ainda no âmbito desse projeto tivemos possibilidade de abrir uma pequena sondagem no interior da gruta com arte esquemática pintada que se esconde por trás do altar da ermida de Nossa Senhora da Lapa, situada na freguesia de Alegrete, concelho de Portalegre (Figura 7).

Decorrente dessas sondagens foi possível obter carvões que foram submetidos a datação e que, se num caso veio confirmar o que seria espectável em termos cronométricos para a fase em que as paredes do abrigo foram decoradas com arte esquemática, o Abrigo da Igreja dos Mouros, já as datas obtidas em sequências estratigráficas no interior do Abrigo Pinho Monteiro, aparentemente nada terão a ver com a arte, igualmente esquemática que decora as paredes do abrigo ou, então, teremos que rever as cronologias das sequenciações estilísticas até agora reconhecidas e aceites.

No decurso dos trabalhos desenvolvidos no abrigo da Igreja dos Mouros foi possível recolher várias amostras de carvões das quais duas foram submetidas a datação. Carvões recolhidos no quadrado E3, situado junto à "pedra de altar" e sob um dos painéis pintados, associados a pequenas concentrações de pasta de cor alaranjada e também branca, semelhantes às cores utilizadas nas pinturas parietais fornece- 
ram a seguinte idade: Beta -336388: $4320+/-30 B P$, que calibrada a 2 sigmas resulta na data: $\mathrm{Cal} \mathrm{BC} 308 \mathrm{O}$ a 3060. Esta data parece estar em linha, quer com os materiais atribuídos aos inícios do calcolítico identificados nos quadrados E5, E6 e D6, quer com as cronologias normalmente consideradas nesta região para a arte esquemática. A outra amostra de carvões submetidos a datação foi recolhida na sondagem aberta em frente do abrigo (D9), no interior do que parece ser uma estrutura em arco de círculo. Esta amostra forneceu a seguinte idade: Beta -336387: $920+/-30$ BP, que calibrada a 2 sigmas resulta numa data no intervalo de: $\mathrm{Cal}$ AD 1020 a 116o. Esta data medieval encontra paralelo com a obtida para um nível superficial de carvões recolhidos no interior do Abrigo Pinho Monteiro que forneceu a seguinte idade: Beta - 296435: 920 +/- 40 BP, que calibrada a 2 sigmas resulta numa data no intervalo de: $\mathrm{Cal}$ AD 1010 a 1170. Esta interessantíssima concordância de datas para abrigos afastados entre si cerca de $4 \mathrm{kms}$ é ainda mais relevante quando verificamos que a denominada Reconquista Cristã desta zona do Alentejo, pelos homens de Afonso Henriques, terá ocorrido entre 1160 e 1170 . Parece assim que a instabilidade que as manobras militares de cristãos e muçulmanos provocavam, especialmente nos núcleos urbanos, levaram alguns a procurar refúgio entre os abrigos naturais existentes na zona, ocupando espaços que milhares de anos antes outros também procuraram. Se para as datas históricas temos concordância entre os dois abrigos por nós escavados, já para épocas mais recuadas tal não se verifica. Observámos que na Igreja do Mouros a data pré-histórica obtida está em concordância com a idade e horizonte culturais atribuídos à Arte Esquemática e com os materiais exumados neste abrigo; contudo afasta-se em muitos milénios, das datas e igualmente dos conjuntos artefactuais identificados no Abrigo Pinho Monteiro, a escassos $4 \mathrm{kms}$ de distância. No Abrigo Pinho Monteiro as duas amostras recolhidas remetem-nos para duas ocupações distintas, uma conotada com momentos dos finais do Paleolítico: Beta - 296433: 9640 +/-50BP, que calibrada a 2 sigmas resulta em: Cal BC 9250 a 9100 e outra mesolítica: Beta - 296434: 8390 +/- 40BP, que calibrada a 2 sigmas resulta em: Cal BC 7570 a 7460 . Parece, assim, que no Abrigo Pinho Monteiro, desde, pelo menos, os finais da última glaciação o homem acendeu aqui fogueiras e, novamente no Mesolítico, voltou a ocupar o lugar e aí a acender fogueiras e onde talhou sílex e quartzos junto à entrada do abrigo. Mais tarde, já pelos finais do Neolítico e durante o Calcolítico, ou mesmo já a entrar na Idade do Bronze, o abrigo Pinho Monteiro voltou a ser ocupado e alguns dos seus utentes para além de erguerem um muro à entrada do abrigo, conforme interpretação de Mário Varela Gomes (1989) (Gomes, 1989, 6) pintaram profusamente o teto mantendo a temática esquemática e cores que variam entre o vermelho e o laranja. Deveremos, contudo, estar disponíveis para reavaliarmos se toda a arte pintada no teto do Abrigo Pinho Monteiro terá mesmo sido realizada em momentos tardios da pré-história / inícios da metalurgia, ou se alguma desta arte não poderá remontará aos finais do Paleolítico ou ao Mesolítico. Se assim for, e suportados nas datas disponíveis e nos artefactos exumados no Abrigo Pinho Monteiro e enquanto não dispusermos de datas diretas das pinturas, deveremos reequacionar o posicionamento crono-cultural, pelos menos de alguma arte, denominada esquemática, que genericamente temos vindo a considerar como mais recente (Figura 8 e 9). Da gruta do interior da Ermida de NNe. Srª . da Lapa, na Freguesia de Alegrete, submetemos a datação um dente extraído dum fragmento de mandíbula de jovem adulto humano que resultou, como seria espectável, atendendo ao contexto e aos de materiais anexos, numa data atribuível aos finais século XVIII A.D. e que corresponde à fase da reforma arquitetónica deste milenar espaço de culto.

Concluindo, porque o espaço disponível é curto, tentámos, de forma muito abreviada, expor as principais conclusões e dúvidas resultantes das mais de trinta datas, que abaixo disponibilizamos, obtidas em sítios e monumentos construídos, erguidos ou ocupados, maioritariamente, durante a Pré-História Recente na região norte do Alentejo e canto noroeste da Extremadura espanhola (Figura 10).

\section{BIBLIOGRAFIA}

BARATA, J. Pedro Martins (1965) - O Menir da Meada, Ethnos, 4, Lisboa.

BOAVENTURA, R. (2006) - Os IV e III milénios a.n.e. na região de Monforte, para além dos mapas com pontos: os casos do cluster de Rabuje e do povoado com fossos de Moreiros 2. Revista Portuguesa de Arqueologia. Lisboa: IPA, 9 (2), pp. 61-73.

BREUIL, Henri (1917) - La roche peinte de Valdejunco à la Esperança, près de Arronches (Portalegre), Terra Portuguesa, 13-14, Fev. - Mar., Lisboa. 
BUENO, Primitiva (1988) - Los Dolmenes de Valencia de Alcantara, Excavaciones Arqueologicas en España ํํำ155, Ministerio de Cultura, Madrid.

Idem (1987) - Megalitismo en Extremadura: Estado de la Cuestión, in El Megalitismo en la Península Ibérica, Ministerio de Cultura, Madrid.

Idem (1988) - Los Dolmenes de Valencia de Alcantara, Excavaciones Arqueologicas en España nํㅗ55, Ministerio de Cultura, Madrid.

Idem (1989) - Camaras Simples en Extremadura, XIX Congreso Nacional de Arqueologia, 1987, Castellón de la Plana.

CANINAS, J. C. Pires e HENRIQUES, F. J. (1985) - Testemunhos do Neolítico e do Calcolítico no Concelho de Nisa, in Actas das $1^{a s}$. Jornadas de Arqueologia do Nordeste Alentejano, Comissão Regional de Turismo e Câmara Municipal de Castelo de Vide, Portalegre.

Idem, (1987) - Megalitismo de Vila Velha de Ródão e Nisa, in Arqueologia no Vale do Tejo, I.P.P.C., Lisboa.

CASTRO, Luís de Albuquerque e; FERREIRA, Octávio da Veiga (196o-61) - As pinturas rupestres esquemáticas da Serra dos Louções, Conímbriga, vol.II-III, 1960-61, pp. 203-229.

GOMES, Mário Varela (1985) - Abrigo de Pinho Monteiro - 1982, Informação Arqueológica, nº 5, IPPC - Departamento de Arqueologia.

GONÇALVES, Vitor et alii (1981) - Anta dos Penedos de S. Miguel (Crato), Campanha 1- (81), Clio, vol. 3, INIC, Lisboa.

HENRIQUES, F.J.R. e CANINAS, J.C.P. (1980) - Contribuição para a carta arqueológica dos concelhos de Vila Velha de Ródão e Nisa, N.R.I.A. Vila Velha de Ródão.

ISIDORO, A. Farinha (1966) - Escavações em dólmenes do Concelho do Crato (Alto Alentejo), Trabalhos de Antropologia e Etnologia, Porto.

LEISNER, George e Vera (1956) - Die Megalithgraber Iberischen Halbinsel.Der Westen (1), Walther de Gruyter, Berlin.

MONTEIRO, J. Pinho, e GOMES, Mário Varela (1977) Os Menires da Charneca do Vale do Sobral - Nisa, Revista de Guimarães, LXXXVII, Guimarães.

OLIVEIRA, Jorge de (1995) - Sepulturas Megalíticas del Termino Municipal de Cedillo - Província de Cáceres - Edición del Ayuntamiento de Cedillo, Cáceres.

OLIVEIRA, Jorge de (1995) - A Recuperação do Menir da Meada - Castelo de Vide, Ed. Câmara Municipal de C. de Vide. (ed. desenvolvida de artoํ. da Ibn Maruán

OLIVEIRA, Jorge de (1997) - Monumentos Megalíticos da Bacia Hidrográfica do Rio Sever, ํํ Vol. - edição bi-lingue, patrocinada pelas Câmaras de Marvão, C. de Vide, Nisa, V. de Alcântara, Herrera de Alcântara e Cedillo e pela Delegação Regional do Ministério da Cultura, Ed. Colibri, Lisboa.
OLIVEIRA, Jorge de (2006) - Património Arqueológico da Coudelaria de Alter, Ed. Colibri / Universidade de Évora, Lisboa.

OLIVEIRA, Jorge (1996) - Datas absolutas de monumentos megalíticos da bacia hidrográfica do Rio Sever, Actas do $2^{\circ}$ Congreso de Aqueologia Peninsular, Zamora.

OLIVEIRA, Jorge (1996) - As pequenas antas de Montalvão e Cedillo, Actas do I Colóquio Internacional sobre Megalitismo de Monsaraz, C.M. de Reguengos de Monsaraz e UNIARQ, Lisboa.

OLIVEIRA, Jorge de; OLIVEIRA, Clara (200o) - Menires do Distrito de Portalegre, Extremadura Arqueológica, Número Especial de Homenagem a Elias Diegués, Cáceres.

OLIVEIRA, Jorge (1999) - Inventario, Investigacion y puesta en Valor de los Dólmenes: Termino Municipal de Cedillo, in Extremadura Restaurada, Consejería de Cultura y Patrimonio de la Junta de Extremadura, Mérida.

OLIVEIRA, Jorge (1996) - As pequenas antas de Montalvão e Cedillo, Actas do I Colóquio Internacional sobre Megalitismo de Monsaraz, C.M. de Reguengos de Monsaraz e UNIARQ, Lisboa.

OLIVEIRA, Jorge de (2001) - O Megalitismo de Xisto da Bacia do Sever Montalvão - Cedillo, Muitas antas pouca gente?, Trabalhos de Arqueologia 16, IPA, Lisboa. 2001.

OLIVEIRA, Jorge de (2003) - A arte rupestre no contexto megalítico Norte-Alentejano, Sinais de Pedra, Fundação Eugénio de Almeida, (ed. electrónica).

OLIVEIRA, Jorge de; Moitas, E; OLIVEIRA, Clara (2007) -Monumentos Megalíticos do Concelho de Arronches, Actas das zas. Jornadas de Arqueologia do Norte-Alentejano.

OLIVEIRA, Jorge de (2007) - The Tombs of the Neolithic Artist-Shepherds of the Tagus Valley, Actas da I Reunión de Estudios sobre la prehistoria reciente en el Tajo internacional, BAR (no prelo).

OLIVEIRA, Jorge de (1998) - A Anta de la Joaniña e a da Era de los Guardias no ambiente megalítico da foz do Sever, Ibn Maruán, n.․ 8, Câmara Municipal de Marvão.

OLIVEIRA, Jorge de (2016) - Cronologias y estratigrafias en el Arte Rupestre de la Sierra de San Mamede (Portugal / España), ARPIn4 4, Universidad de Alcalá de Henares, Madrid.

OLIVEIRA, Jorge de (2016) - O Menhir do Patalou - Nisa, entre contextos e cronologias, in Terra e Água, escolher sementes, invocar a Deusa, Centro de Arqueologia da Universidade de Lisboa, Lisboa.

OLIVEIRA, Jorge de (2019) - O que nos escondem as mamoas e a problemática das datações absolutas no Norte do Alentejo, Scientia Antiquitatibus, nº̣, Évora.

PINTO, Serpa Pinto (1932) - O abrigo pré-histórico de Valdejunco (Esperança), Trabalhos da Sociedade Portuguesa de Antropologia e Etnologia, nํㅜ 5, Porto. 
ROCHA, Leonor (2020) - A Anta da Tapada do Castelo, Santo António das Areias, Marvão. In Memórias de St. Ant ${ }^{\circ}$. das Areias e Beirã , (no prelo).

SOARES, A. M. e CABRAL, J. M. P. (1984) - Datas convencionais de radiocarbono para estações arqueológicas portuguesas e a sua calibração: revisão crítica, O Arqueólogo Português, vol. II, série IV, Lisboa.

\begin{tabular}{|c|c|c|c|}
\hline SÍTIO / LAB. / REF. & IDADE BP & CAL BC / AD & COMENTÁRIO \\
\hline $\begin{array}{l}\text { Anta da Bola da Cera-Marvão } \\
(\text { ICEN-66) }\end{array}$ & $4360 \pm 50$ & $3258-2900$ & $\begin{array}{l}\text { Ossos humanos carbonizados junto a placa de xisto } \\
\text { de recorte antropomórfico, na base da câmara. Anta de } \\
\text { corredor curto. }\end{array}$ \\
\hline $\begin{array}{l}\text { Anta das Castelhanas-Marvão } \\
\text { (amostra 2 ICEN-1264) }\end{array}$ & $6360 \pm 110$ & $5448-5059$ & $\begin{array}{l}\text { Carvões na base da câmara, junto a pontas de seta de base } \\
\text { reta e convexa, em xisto. Anta de corredor curto. }\end{array}$ \\
\hline $\begin{array}{l}\text { Anta das Castelhanas - Marvão } \\
(\text { ICEN-1263) }\end{array}$ & $780 \pm 60$ & $\begin{array}{l}1165-1303 \\
\text { cal AD }\end{array}$ & $\begin{array}{l}\text { Mancha de carvões a pouca profundidade no interior } \\
\text { da câmara. }\end{array}$ \\
\hline $\begin{array}{l}\text { Anta das Castelhanas - Marvão } \\
\text { (amostra 1 OXA-5432) }\end{array}$ & $3220 \pm 65$ & $1630-1320$ & $\begin{array}{l}\text { Ossos humanos carbonizados, junto a vasos semiesféricos } \\
\text { lisos, pontas de seta de base convexa e fragmentos de placa } \\
\text { de xisto. Anta de corredor curto. }\end{array}$ \\
\hline $\begin{array}{l}\text { Anta da Cabeçuda - Marvão } \\
\text { (amostra 1-ICEN-977) }\end{array}$ & $3650 \pm 110$ & $2328-1698$ & $\begin{array}{l}\text { Carvões no interior de "silo" na base da câmara, junto } \\
\text { a taças abertas lisas. Anta de corredor curto. }\end{array}$ \\
\hline $\begin{array}{l}\text { Anta da Cabeçuda-Marvão } \\
\text { (amostra 2-ICEN-978) }\end{array}$ & $7660 \pm 60$ & $6593-6378$ & $\begin{array}{l}\text { Carvões no interior da câmara sobre o solão granítico. } \\
\text { Anta de corredor curto. }\end{array}$ \\
\hline $\begin{array}{l}\text { Anta da Cabeçuda - Marvão } \\
\text { (amostra 3-ICEN 979) }\end{array}$ & $3720 \pm 45$ & $2274-1971$ & $\begin{array}{l}\text { Landes / bolotas carbonizadas sob os esteios tombados } \\
\text { no interior da câmara, junto a fragmentos de cerâmicas } \\
\text { lisas. Anta de corredor curto. }\end{array}$ \\
\hline $\begin{array}{l}\text { Anta da Figueira Branca } \\
\text { - Marvão } \\
\text { ICEN }-823\end{array}$ & $6210 \pm 50$ & $5302-5007$ & $\begin{array}{l}\text { Carvões na base da mamoa em lareira não estruturada, } \\
\text { junto a elemento de mó (dormente). Anta de corredor } \\
\text { curto. }\end{array}$ \\
\hline $\begin{array}{l}\text { Anta da Tapada do Castelo } \\
\text { - Marvão } \\
\text { Beta }-409557\end{array}$ & 2220 & $295-230$ & $\begin{array}{l}\text { Ossos humanos em terras revolvidas por violação da } \\
\text { câmara. (Rocha, L.(2020); A Anta da Tapada do Castelo... } \\
\text { in Memórias de St. Ant } t^{o} \text {. das Areias e Beirã , no prelo.) }\end{array}$ \\
\hline $\begin{array}{l}\text { Anta da Tapada do Castelo } \\
\text { - Marvão } \\
\text { Beta }-506380\end{array}$ & 356 & $1980-1868$ & $\begin{array}{l}\text { Dente de ovicaprídeo . (Rocha,L.(2O20); A Anta da Tapada } \\
\text { do Castelo......in Memórias de St.Ant }{ }^{\circ} \text {.das Areias e Beirã, } \\
\text { no prelo.) }\end{array}$ \\
\hline $\begin{array}{l}\text { Anta dos Coureleiros } 1 \\
\text {-C. de Vide } \\
\text { ICEN-592 }\end{array}$ & $840 \pm 70$ & $\begin{array}{l}1010-1230 \\
\text { cal AD }\end{array}$ & $\begin{array}{l}\text { Carvões junto ao esteio de cabeceira a pouca profundidade } \\
\text { em ambiente de lareira não estruturada }\end{array}$ \\
\hline $\begin{array}{l}\text { Anta dos Coureleiros } 2 \\
\text {-C. de Vide } \\
\text { ICEN-593 }\end{array}$ & \pm 130 & $\begin{array}{l}1280-1330 \\
\text { cal AD }\end{array}$ & $\begin{array}{l}\text { Mancha de carvões a pouca profundidade no interior } \\
\text { da câmara. }\end{array}$ \\
\hline $\begin{array}{l}\text { Anta dos Coureleiros } 4 \\
\text {-C. de Vide } \\
\text { ICEN-976 }\end{array}$ & $4240 \pm 150$ & $3335-2459$ & $\begin{array}{l}\text { Carvões no interior do corredor, junto a placa de xisto } \\
\text { de contorno e decoração geométricos. Anta de corredor } \\
\text { longo. }\end{array}$ \\
\hline $\begin{array}{l}\text { Anta da Horta - Alter do Chão } \\
\text { (AH-Oıo-BETA) }\end{array}$ & $4390 \pm 40$ & $3350-3020$ & $\begin{array}{l}\text { Ossos humanos na entrada do corredor junto a placas } \\
\text { de xisto e arenito, machados, cerâmicas várias,... }\end{array}$ \\
\hline $\begin{array}{l}\text { Anta da Horta-Alter do Chão } \\
\text { (AH-Mi1-BETA) }\end{array}$ & $4190 \pm 50$ & $2930-2860$ & $\begin{array}{l}\text { Ossos humanos não interior da câmara, junto a placa } \\
\text { de xisto. Anta de corredor indeterminado. }\end{array}$ \\
\hline $\begin{array}{l}\text { Anta da Várzea Grande }- \text { Alter } \\
\text { do Chão } \\
\text { Beta }-214598\end{array}$ & $180 \pm 40$ & $\begin{array}{l}1740-1810 \\
\text { cal AD }\end{array}$ & $\begin{array}{l}\text { Dente de equídeo retirado de conjunto de várias peças } \\
\text { óssea depositadas a pouca profundidade no interior } \\
\text { da câmara funerária. }\end{array}$ \\
\hline $\begin{array}{l}\text { Anta de S. Gens II - Nisa } \\
\text { Beta }-409561\end{array}$ & $4340 \pm 30$ & $3094-2914$ & Ossos humanos em revolvimento interior da câmara \\
\hline
\end{tabular}

Tabela 1 - Datas absolutas obtidas em sítios da Pré-História recente do Alto Alentejo. 


\begin{tabular}{|c|c|c|c|}
\hline SÍTIO / LAB. / REF. & IDADE BP & CALBC / AD & COMENTÁRIO \\
\hline $\begin{array}{l}\text { Anta da Lomba da Barca-Nisa } \\
\text { ICEN-1124 }\end{array}$ & $950 \pm 80$ & $966-1272$ & $\begin{array}{l}\text { Carvões por entre os fragmentos dos esteios tombados } \\
\text { no interior da câmara. Pequeno sepulcro em xisto. }\end{array}$ \\
\hline $\begin{array}{l}\text { Anta da Joañina-Cedillo } \\
\text { (Espanha) } \\
(\text { amostra B-SAC-138o) }\end{array}$ & $5400 \pm 210$ & $4710-3770$ & $\begin{array}{l}\text { Carvões sob o lajeado junto ao solão de base, sem } \\
\text { materiais associados. Pequeno sepulcro em xisto. }\end{array}$ \\
\hline $\begin{array}{l}\text { Anta da Joañina-Cedillo } \\
\text { (Espanha) } \\
(\text { amostra } A-S A C-1381)\end{array}$ & $3840 \pm 170$ & $2870-2720$ & $\begin{array}{l}\text { Carvões sobre o lajeado da base do monumento, junto } \\
\text { a machado de anfibolito e ponta de seta e lâmina de sílex. } \\
\text { Pequeno sepulcro em xisto. }\end{array}$ \\
\hline $\begin{array}{l}\text { Anta da Charca Grande de la } \\
\text { Regañada-Cedillo (Espanha) } \\
\text { Beta }-409562\end{array}$ & $1110 \pm 30$ & $\begin{array}{l}895-1020 \\
\text { cal AD }\end{array}$ & $\begin{array}{l}\text { Carvões recolhidos no interior da câmara sobre o solão } \\
\text { de base }\end{array}$ \\
\hline $\begin{array}{l}\text { Menhir da Meada-C. de Vide } \\
\text { UtC }-445^{2}\end{array}$ & $6022 \pm 40$ & $5010-4810$ & $\begin{array}{l}\text { Carvões no interior do alvéolo de implantação do menhir, } \\
\text { junto à sua base. }\end{array}$ \\
\hline $\begin{array}{l}\text { Menhir do Patalou - Nisa } \\
\text { Beta }-416341\end{array}$ & $5420 \pm 30$ & $4340-4235$ & $\begin{array}{l}\text { Carvões no interior do alvéolo de implantação do menhir, } \\
\text { junto à sua base. }\end{array}$ \\
\hline $\begin{array}{l}\text { Menhir do Carvalhal } \\
\text { - C. de Vide } \\
\text { ICEN } 1126\end{array}$ & $760 \pm 50$ & $\begin{array}{l}1213-1303 \\
\text { cal AD }\end{array}$ & $\begin{array}{l}\text { Carvões no interior do alvéolo por entre os calços } \\
\text { de sustentação do menhir. }\end{array}$ \\
\hline $\begin{array}{l}\text { Menhir do Carvalhal } \\
\text { - C. de Vide } \\
\text { ICEN } 1125\end{array}$ & $420 \pm 60$ & $\begin{array}{l}1409-1641 \\
\text { cal AD }\end{array}$ & Carvões sobre os calços de sustentação do menhir. \\
\hline $\begin{array}{l}\text { Abrigo Igreja dos Mouros } \\
\text { - Arronches } \\
\text { Beta }-336388\end{array}$ & $4320 \pm 30$ & $3080-3060$ & $\begin{array}{l}\text { Carvões junto a concentrações de pasta de cor laranja } \\
\text { e branca, sob painel pintado com as mesmas cores. }\end{array}$ \\
\hline $\begin{array}{l}\text { Abrigo Igreja dos Mouros } \\
\text { - Arronches } \\
\text { Beta }-336387\end{array}$ & $920 \pm 30$ & $\begin{array}{l}1020-1160 \\
\text { cal AD }\end{array}$ & $\begin{array}{l}\text { Carvões associados a estrutura semicircular no exterior } \\
\text { do abrigo. }\end{array}$ \\
\hline $\begin{array}{l}\text { Abrigo Pinho Monteiro } \\
\text { - Arronches } \\
\text { Beta }-296433\end{array}$ & $9640 \pm 50$ & $9250-9100$ & $\begin{array}{l}\text { Carvões sobre a rocha de base no interior do abrigo } \\
\text { associado a indústria mico-laminar em quartzo. }\end{array}$ \\
\hline $\begin{array}{l}\text { Abrigo Pinho Monteiro } \\
\text { - Arronches } \\
\text { Beta }-296434\end{array}$ & $8390 \pm 40$ & $7570-7460$ & $\begin{array}{l}\text { Carvões sobre a rocha de base encostados à parede lateral } \\
\text { direita junto a indústrias micro-laminares. }\end{array}$ \\
\hline $\begin{array}{l}\text { Abrigo Pinho Monteiro } \\
\text { - Arronches } \\
\text { Beta }-296435\end{array}$ & $960 \pm 40$ & $\begin{array}{l}1010-1170 \\
\text { cal AD }\end{array}$ & $\begin{array}{l}\text { Larga mancha de carvões a } 15 \mathrm{~cm} \text { da superfície no interior } \\
\text { do abrigo }\end{array}$ \\
\hline $\begin{array}{l}\text { Gruta da Ermida da Sr }{ }^{\text {a }} \text {. } \\
\text { da Lapa - Portalegre } \\
\text { Beta }-409560\end{array}$ & $130 \pm 30$ & $\begin{array}{l}1645-1685 \\
\text { cal AD }\end{array}$ & $\begin{array}{l}\text { Dente de jovem adulto humano, extraído de fragmento } \\
\text { de mandíbula, junto a derrubes do antigo altar }\end{array}$ \\
\hline $\begin{array}{l}\text { Habitat P.-H. da Pedra da Águia } \\
\text { - Alter do Chão } \\
\text { Beta }-215978\end{array}$ & $1720 \pm 40$ & $\begin{array}{l}130-350 \\
\text { cal AD }\end{array}$ & Metacarpo de bovídeo com sinais de corte. \\
\hline $\begin{array}{l}\text { Locus } 1 \text { Porta do Tempo } \\
\text { - Alter do Chão } \\
\text { Beta-194311 }\end{array}$ & $3220 \pm 40$ & $1530-1400$ & $\begin{array}{l}\text { Carvões de habitat aberto com cerâmicas lisas e elementos } \\
\text { de mó, nas imediações da Anta da Horta. }\end{array}$ \\
\hline
\end{tabular}

Tabela 1 (Continuação). 


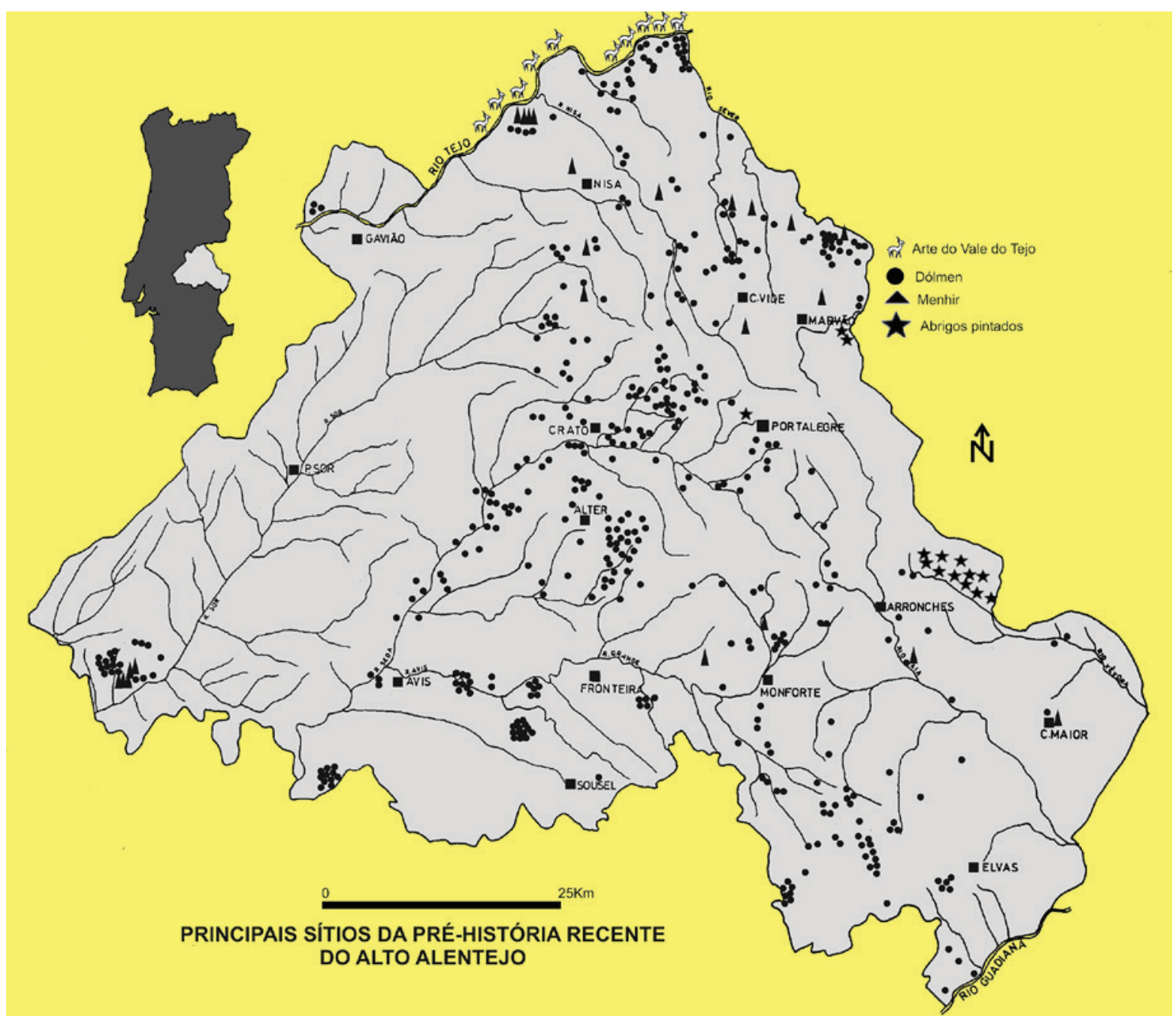

Figura 1 - Mapa: Principais sítios da Pré-História recente do Alto Alentejo.

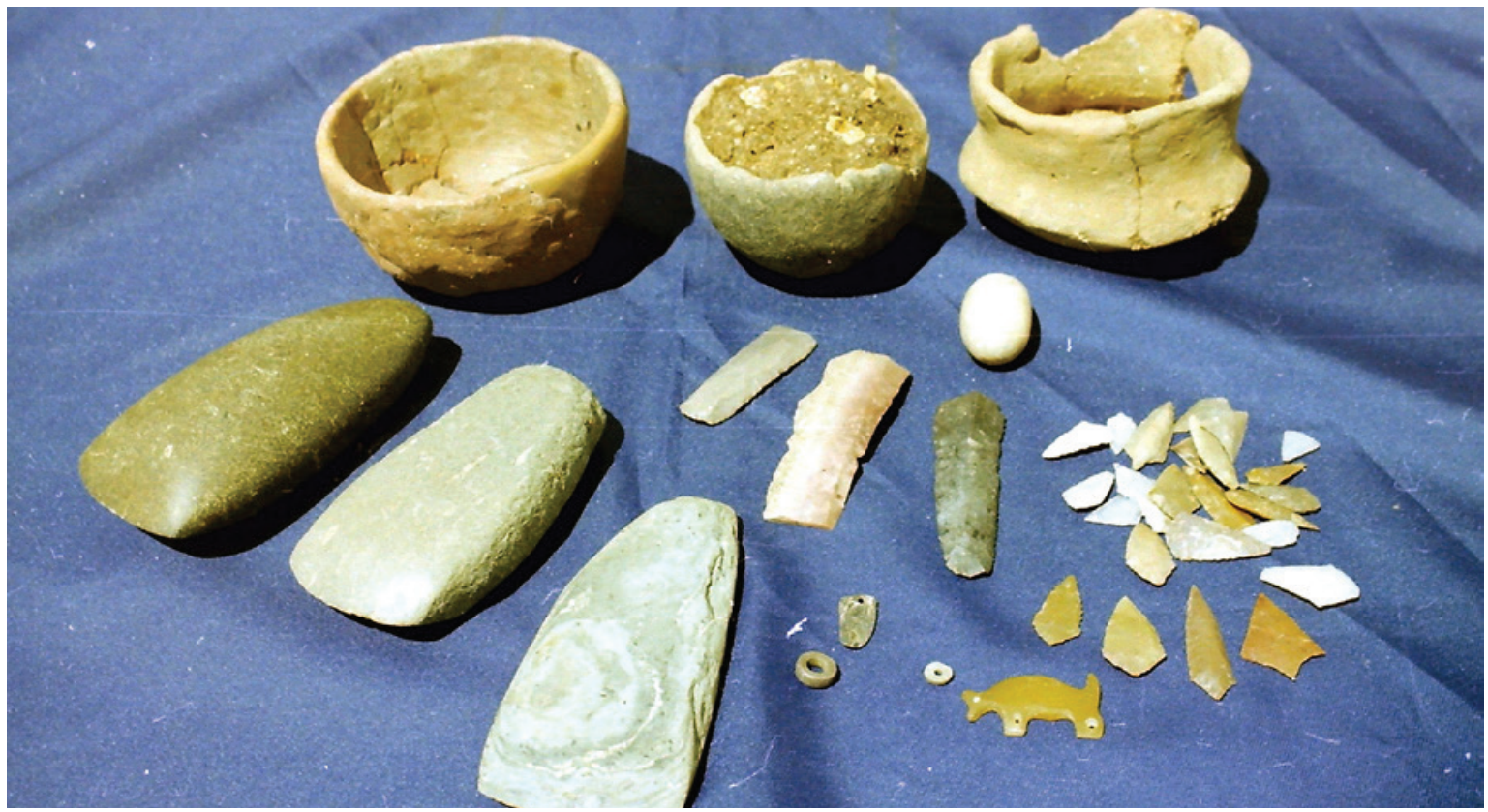

Figura 2 - Anta da Tapada de Matos (Castelo de Vide): materiais recolhidos no corredor. 


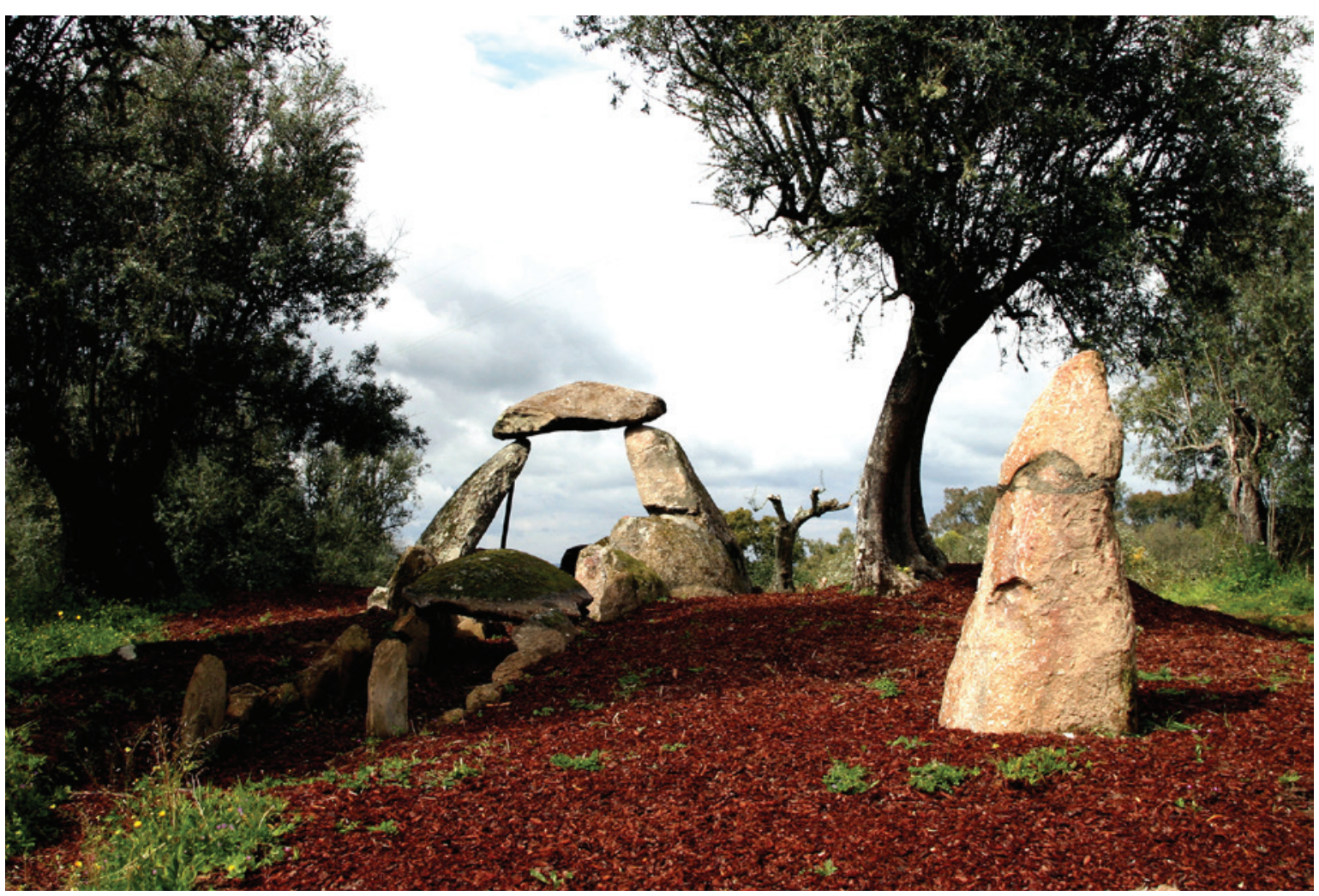

Figura 3 - Anta e Menhir da Soalheira (Alter do Chão).

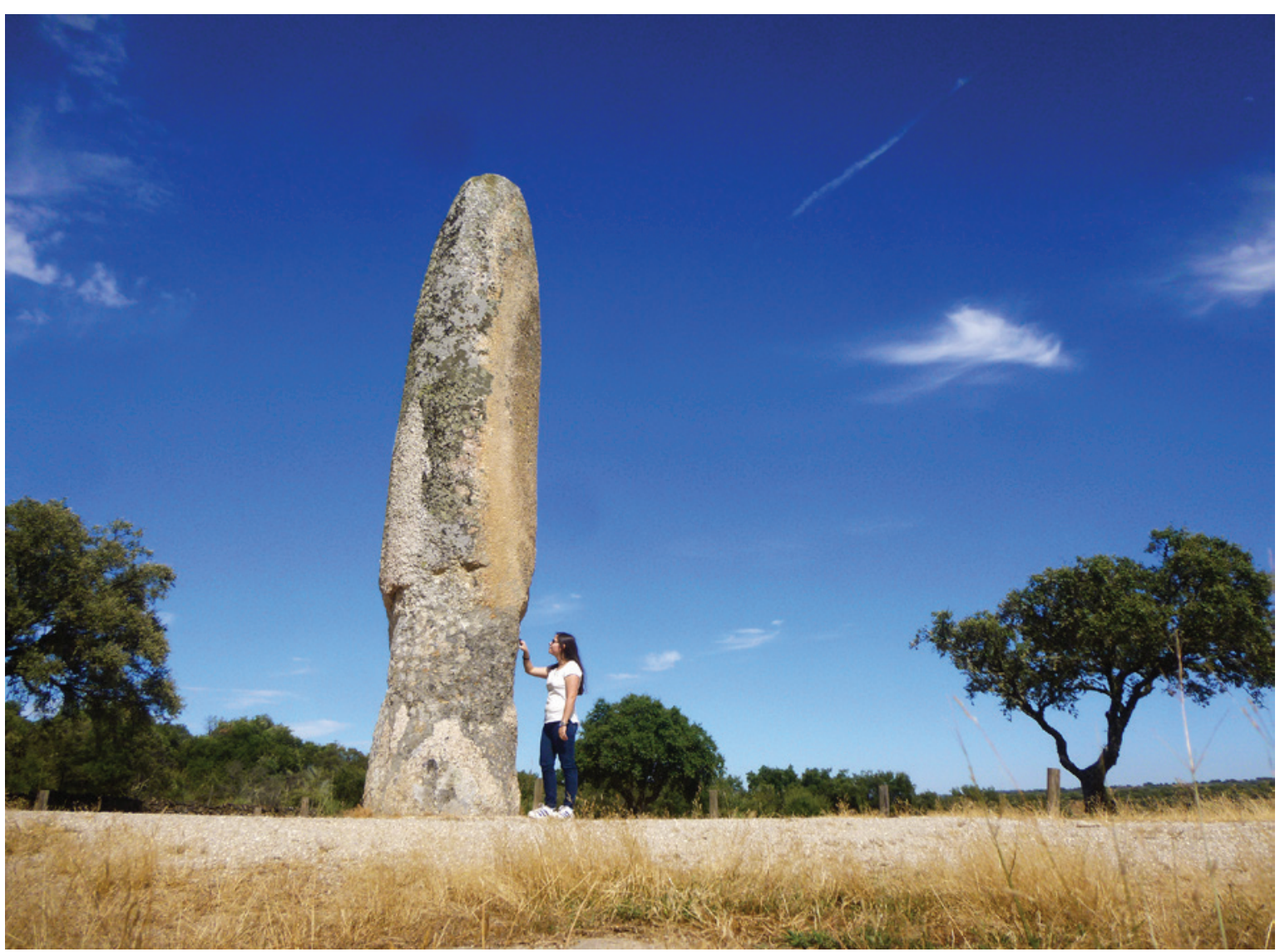

Figura 4 - Menhir da Meada (Castelo de Vide). 


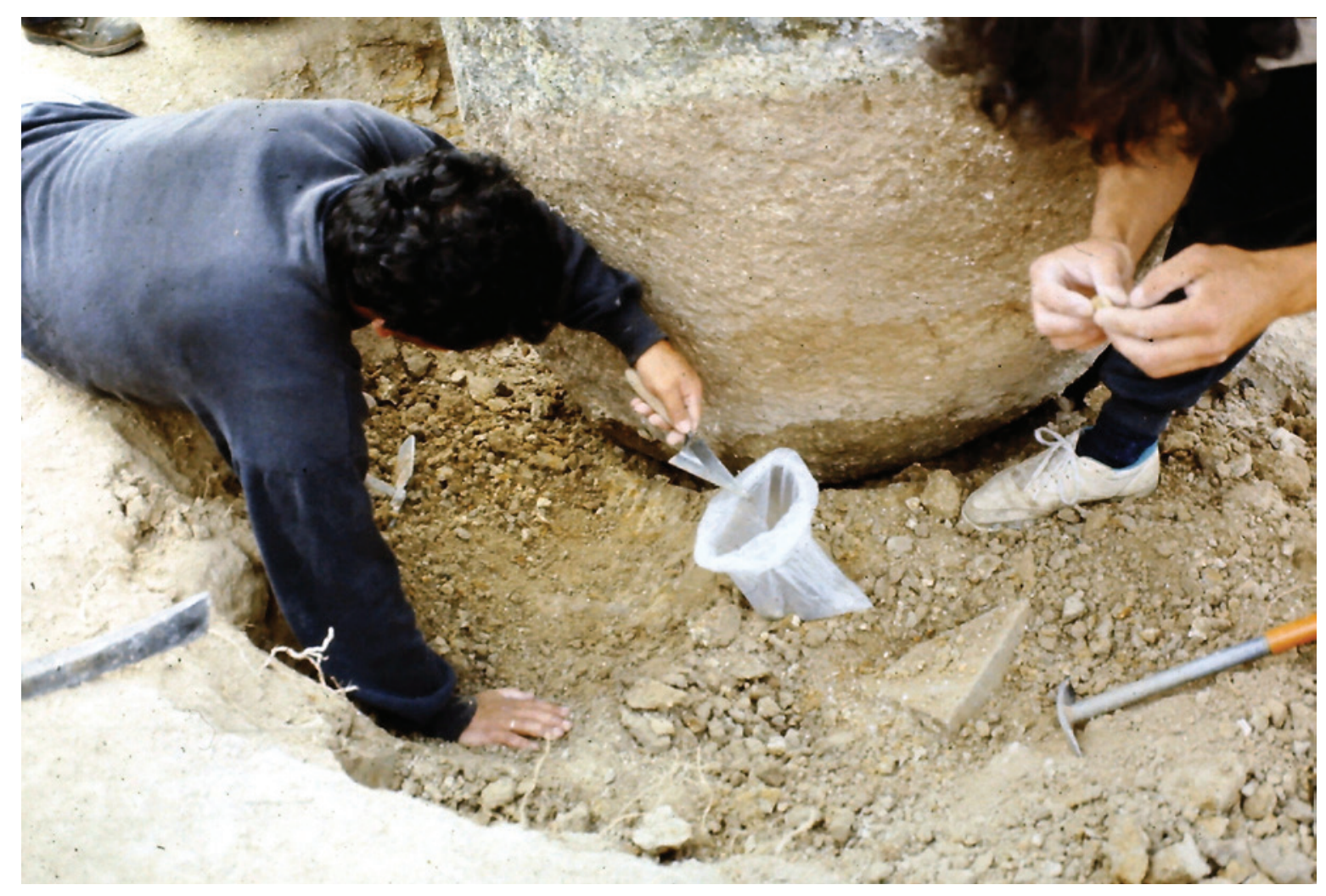

Figura 5-Menhir da Meada: recolha de carvões no interior do alvéolo, junto à base do monumento.

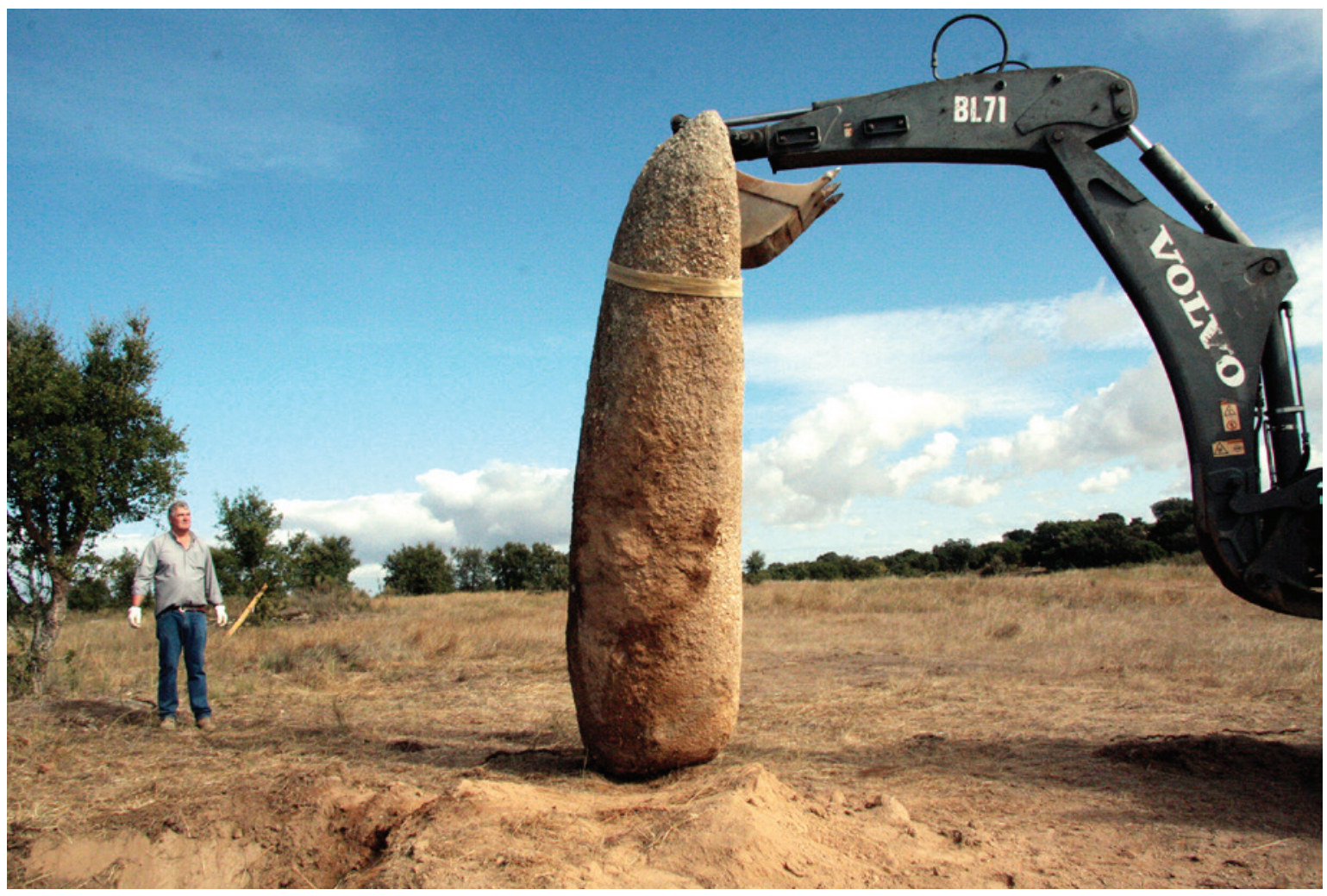

Figura 6 - Menhir do Patalou (Nisa). 


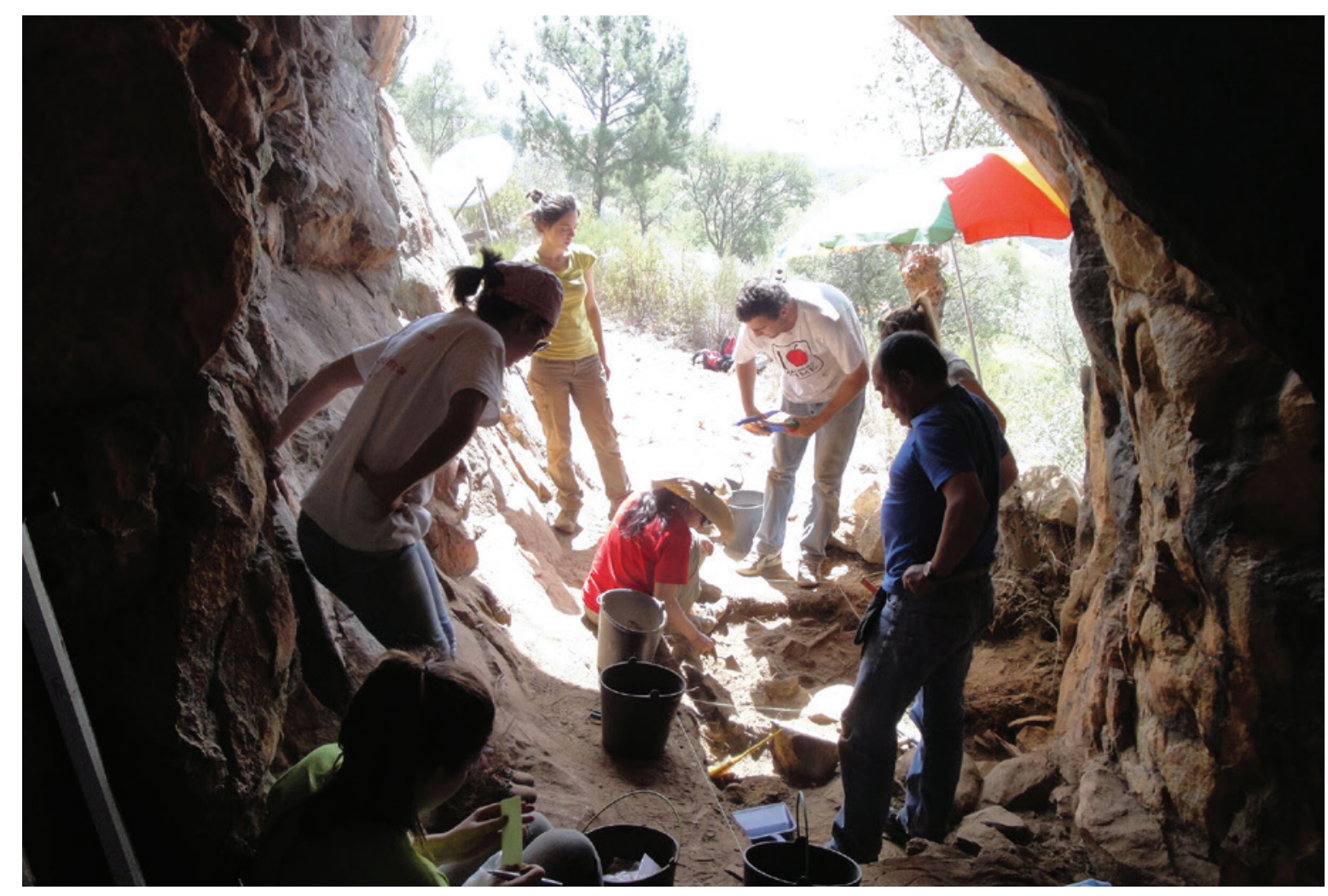

Figura 7 - Abrigo da Igreja dos Mouros (Arronches): vista geral da escavação.

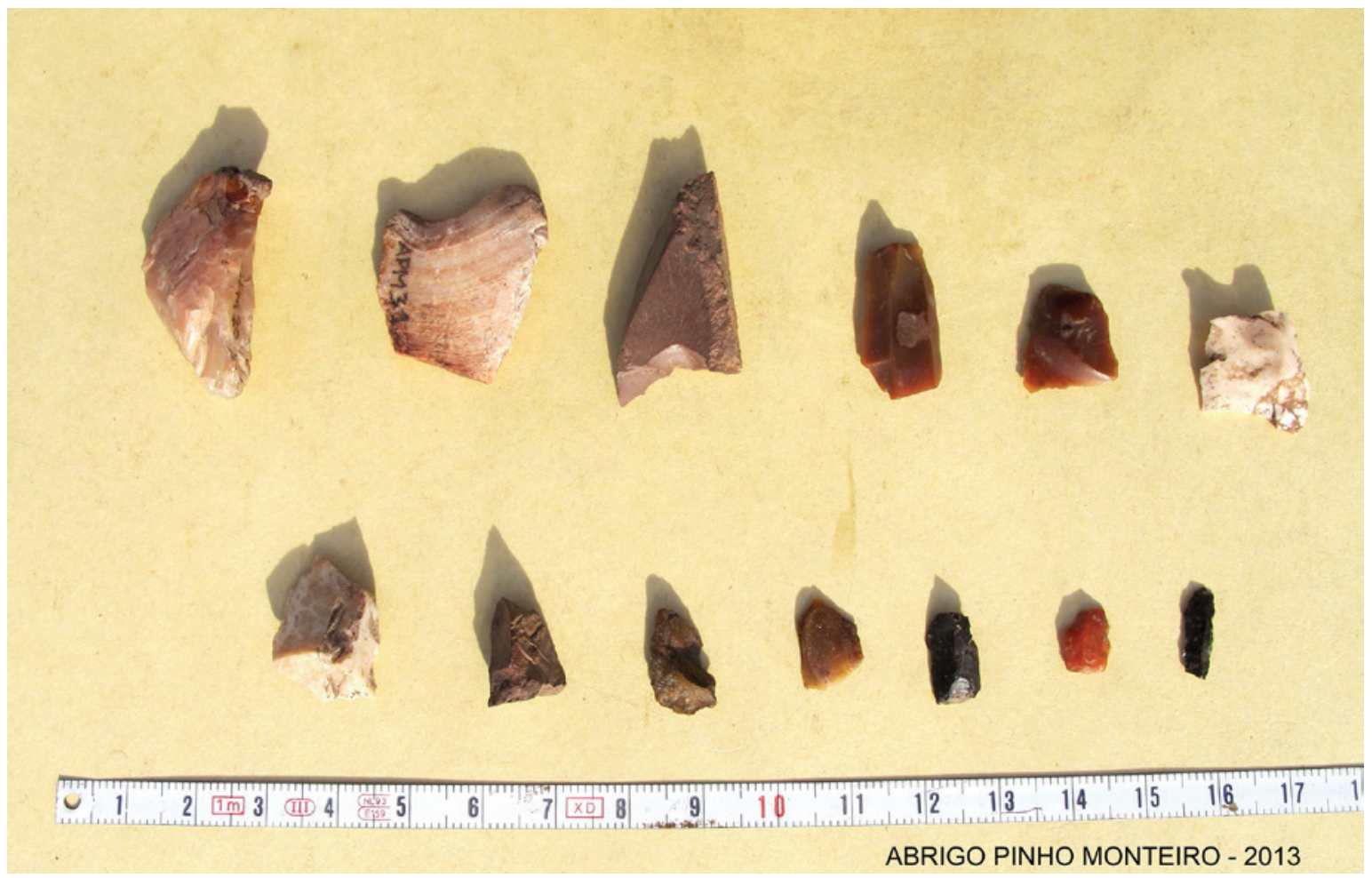

Figura 8-Abrigo Pinho Monteiro (Arronches): indústria lítica da base do abrigo. 


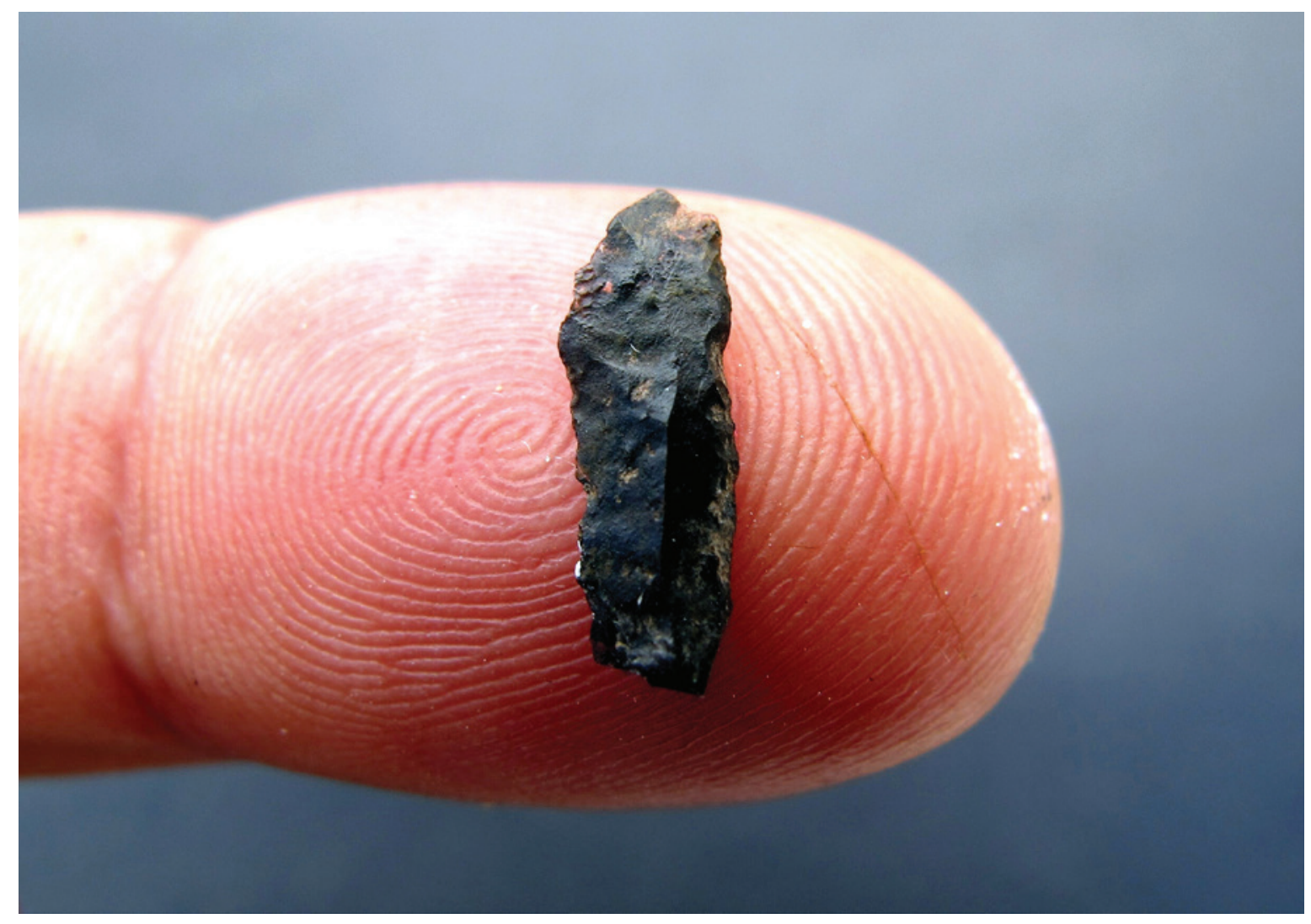

Figura 9-Abrigo Pinho Monteiro (Arronches): lamela de sílex recolhida na base do abrigo. 



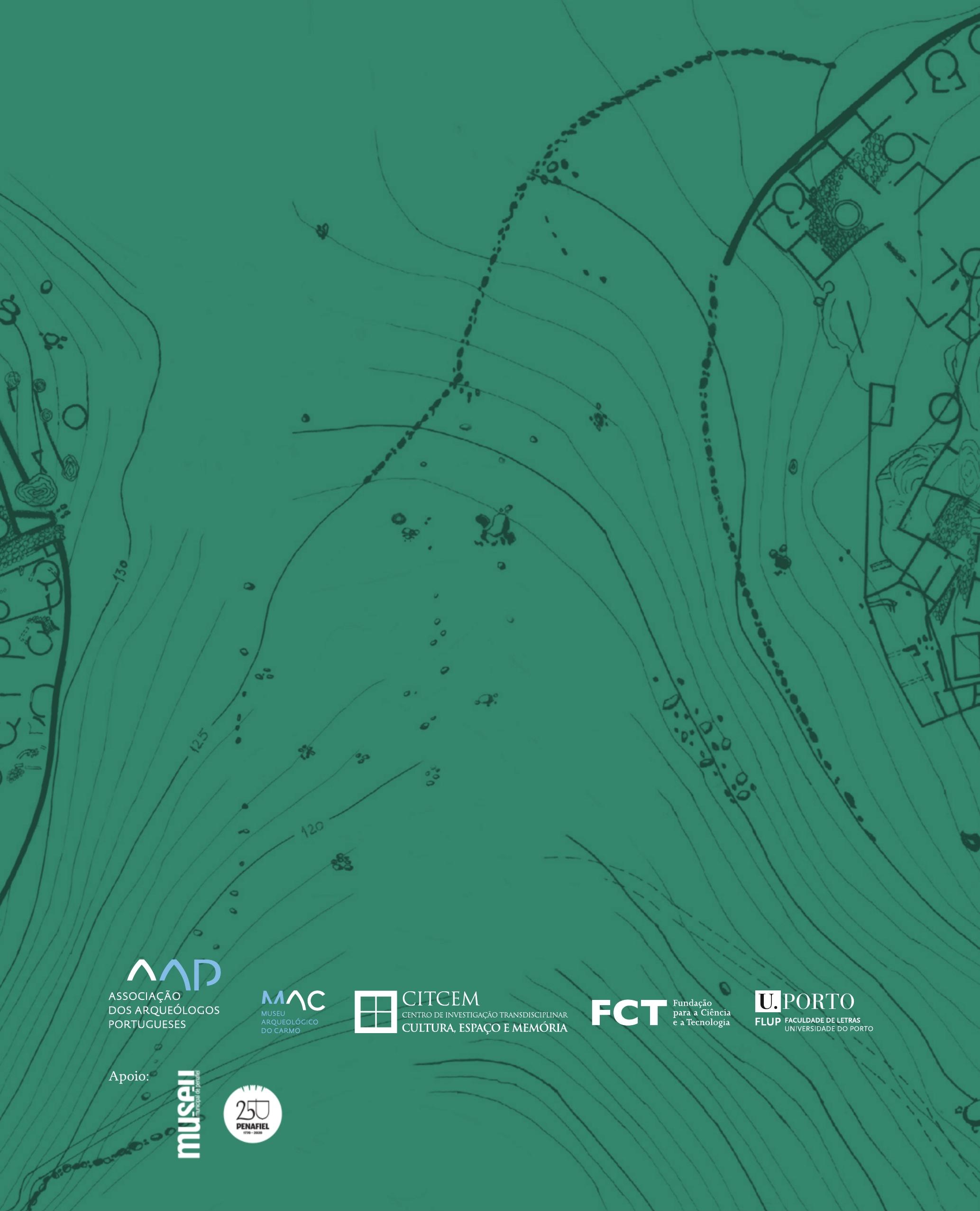

